Portland State University

PDXScholar

8-2-1991

\title{
The Physiology and Molecular Biology of Iron Nutrition for Cyanobacteria
}

Nancy Walters Unsworth

Portland State University

Follow this and additional works at: https://pdxscholar.library.pdx.edu/open_access_etds

Part of the Biology Commons

Let us know how access to this document benefits you.

Recommended Citation

Unsworth, Nancy Walters, "The Physiology and Molecular Biology of Iron Nutrition for Cyanobacteria" (1991). Dissertations and Theses. Paper 4529.

https://doi.org/10.15760/etd.6413

This Thesis is brought to you for free and open access. It has been accepted for inclusion in Dissertations and Theses by an authorized administrator of PDXScholar. Please contact us if we can make this document more accessible: pdxscholar@pdx.edu. 
AN ABSTRACT OF THE THESIS OF Nancy Walters Unsworth for the Master of Science in Biology presented August 2, 1991.

Title: The Physiology and Molecular Biology of Iron Nutrition for Cyanobacteria.

APPROVED BY THE MEMBERS OF THE THESIS COMMITTEE:

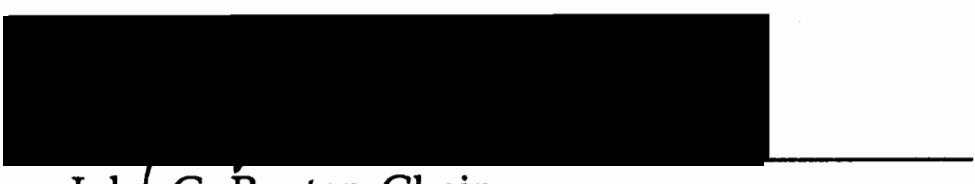

John G. Rueter, Chair
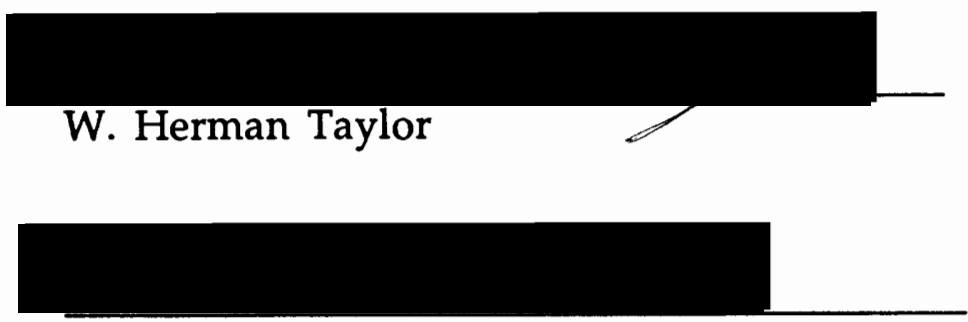

Richard R. Petersen

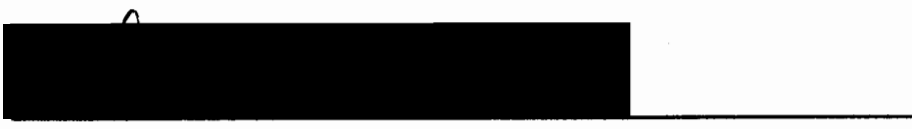

Dennis Barnum

In addition to nitrogen and phosphorus, iron is an essential nutrient for oceanic primary productivity. Unlike nitrogen and phosphorus however, negligible amounts of iron are supplied to surface waters through recycling or mixing but instead from the limited and sporadic input of aeolian particulate. The low concentration of iron that becomes biologically available from the dust places a serious constraint on the heavily iron-dependent processes of photosynthesis and nitrate reduction which affect primary productivity. As 
much as $47 \%$ of the total oceanic primary productivity can be attributed to cyanobacteria making them critical organisms in the biogeochemical cycles. This thesis addresses the effect of iron on primary productivity using a combined approach of physiological and molecular biology.

The physiological response of three marine strains of Synechococcus to growth on different concentrations of FeEDTA was investigated. Cells grown with higher concentrations of iron had greater cell density, more Chl-a and phycobiliproteins and higher carbon fixation rates than cells grown at limiting iron concentrations $\left(10^{-8} \mathrm{M} \mathrm{Fe}\right)$. Iron enrichment of iron limited cultures stimulated carbon fixation, growth rate, and pigment and protein synthesis. Iron limited cells spiked with $5 \mu \mathrm{M} \mathrm{NH}{ }_{4} \mathrm{Cl}$ prior to short term incubations had higher dark carbon fixation than cells grown at higher iron and also spiked to $5 \mu \mathrm{M} \mathrm{NH} \mathrm{NH}_{4} \mathrm{Cl}$. The addition of ammonium relieves a restricted nitrogen assimilatory pathway in the low iron cells that is evidenced by increased dark carbon fixation. We propose that this measurement of enhanced dark carbon fixation could be a useful assay in supporting the contention that populations of Synechococcus in nitrate rich waters are iron limited.

Molecular genetic techniques were used to look for the presence of an iron uptake gene in cyanobacteria. Preliminary results indicate that there is a gene that is homologous to the ferric uptake regulation (fur) gene in E. coli . This hybridization occurred in siderophore-producing cyanobacteria, but not in marine cyanobacteria that do not produce siderophores. The fact that marine Synechococcus do not produce siderophores and did not hybridize to the fur gene suggest that fundamentally different mechanisms for iron 
uptake operate in high biomass freshwater cyanobacteria and cyanobacteria from dilute oligotrophic waters. 


\title{
THE PHYSIOLOGY AND MOLECULAR BIOLOGY OF IRON NUTRITION
} FOR CYANOBACTERIA

\author{
by \\ NANCY WALTERS UNSWORTH
}

\begin{abstract}
A thesis submitted in partial fulfillment of the requirements for the degree of
\end{abstract}

\section{MASTER OF SCIENCE \\ in BIOLOGY}

Portland State University

1992 
TO THE OFFICE OF GRADUATE STUDIES:

The members of the Committee approve the thesis of Nancy Walters Unsworth presented August 2, 1991.

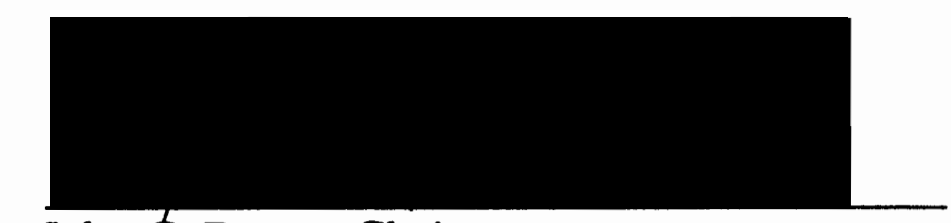

John \&. Rueter, Chair

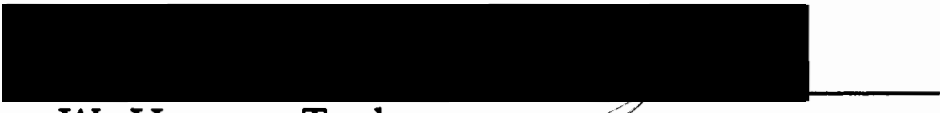

W. Herman Taylor

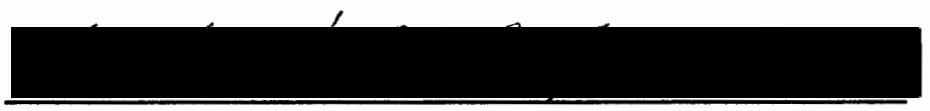

Richard R. Petersen

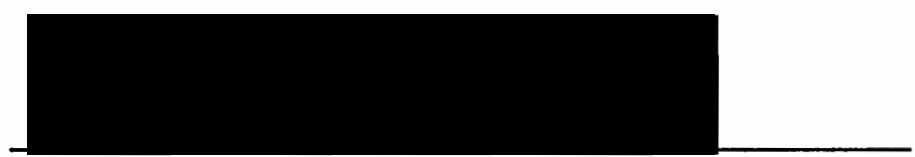

Dennis Barnum

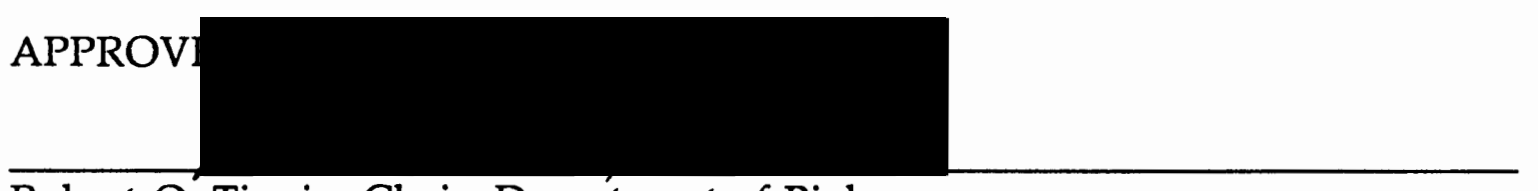

Robert O. Tinnin, Chair, Department of Biology

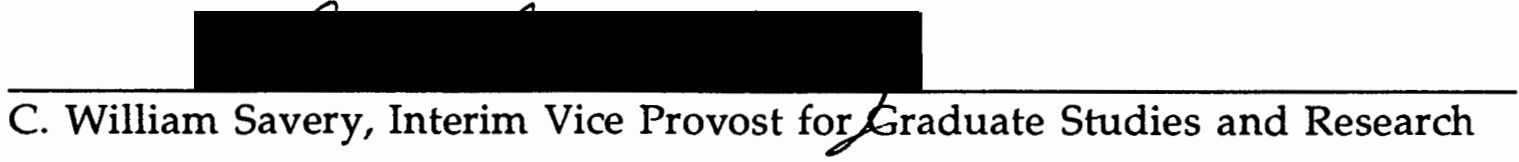




\section{ACKNOWLEDGEMENTS}

I would like to thank first and foremost, John Rueter whose unending support and faith in my ability to succeed generated a new sense of excitement and self confidence that convinced me I was capable of this task. I would also like to thank Karen Elardo for many months of moral support, trips to the coffee shop and companionship in the lab Finally, I thank my husband Dave for his valuable computer skills and for the endless amount patience he continually shows with me. 


\section{TABLE OF CONTENTS}

PAGE

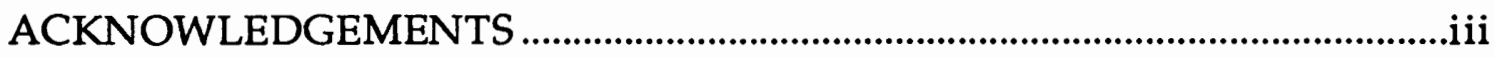

LIST OF TABLES....................................................................................................vi

LIST OF FIGURES.................................................................................................

\section{CHAPTER}

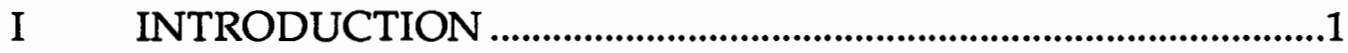

II INCREASED PIGMENT SYNTHESIS IN CULTURES AND NATURAL SAMPLES OF CYANOBACTERIA DUE TO IRON ADDITIONS ....................................................................

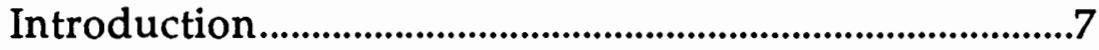

Materials and Methods.............................................................9

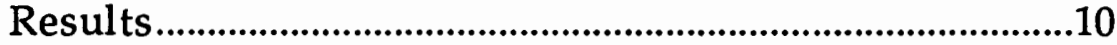

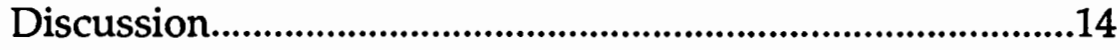

III ENHANCEMENT OF DARK CARBON FIXATION IN IRON-LIMITED CULTURES OF SYNECHOCOCCUS

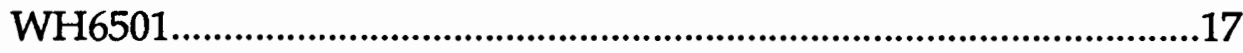

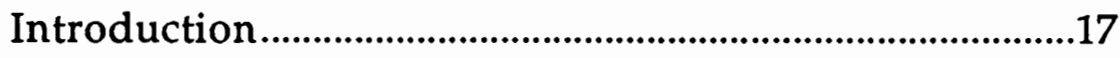

Materials and Methods.......................................................18

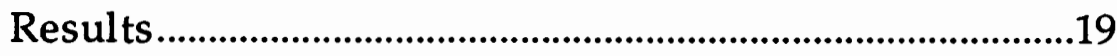

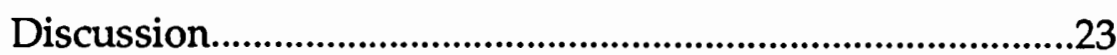

IV IRON REGULATION AT THE GENETIC LEVEL: DO CYANOBACTERIA POSSESS A SEQUENCE HOMOLOGOUS TO THE E. COLI FERRIC UPTAKE

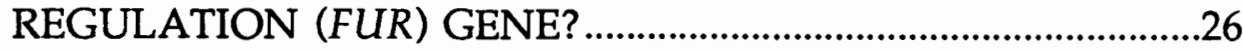

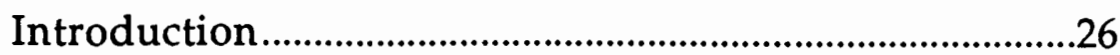




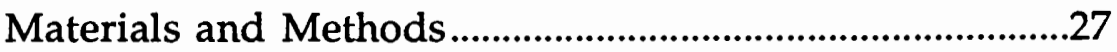

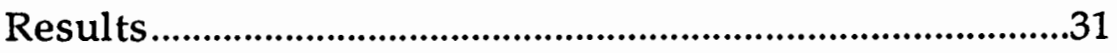

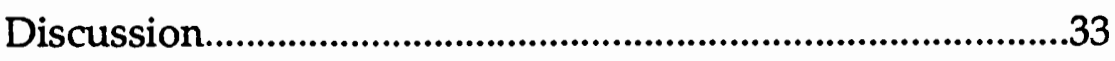

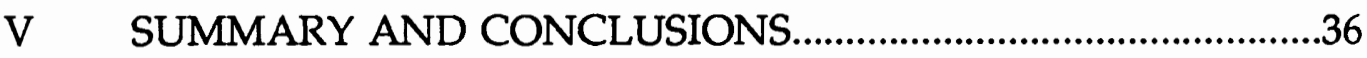

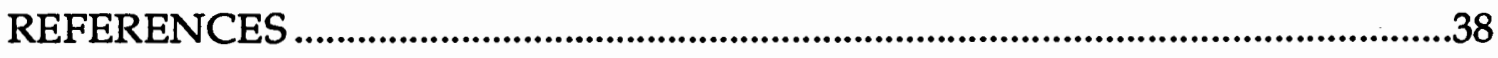

APPENDICES

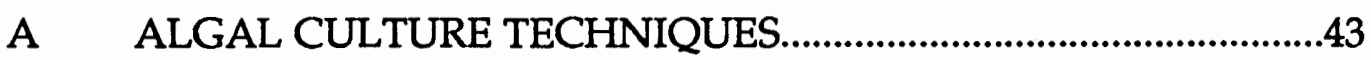

B BIOCHEMICAL AND PHYSIOLOGICAL TECHNIQUES.............48

C MOLECULAR BIOLOGY TECHNIQUES.....................................55 


\section{LIST OF TABLES}

I The Effect of Iron on Phycobilin Content of Synechococcus WH7803 After Six Days (the Data are the Mean of Two Experiments \pm Range).

II Increase in ALA synthesis rate in Synechococcus WH6501 cultures preincubated with $5 \times 10^{-7} \mathrm{M}$ Fe for 16 hours......

III Short term reponse (13 hours) of Chl-a and phycoerythrin synthesis in Trichodesmium to added iron

IV Cellular parameters and dark carbon fixation rate for four experiments. "Experiment a" was measured after four days and $b, c$ and $d$ were measured after 5 days......20

V Carbon fixation rate for cells grown in the light with no ammonium added. Relative carbon fixation given in counts per minute per microgram Chl-a.....................21 


\section{LIST OF FIGURES}

FIGURE

PAGE

1. Growth response of Synechococcus strains WH6501, WH7803 and WH8018 to a range of iron concentrations $\left(10^{-9} \mathrm{M}\right.$ Fe-10-6 $\left.\mathrm{M} \mathrm{Fe}\right)$

2. Measurement of total cellular protein per milliliter of culture for the three Synechococcus strains studied.....11

3. Chl-a concentration for the three Synechococcus strains sampled.

4. Growth response of Synechococcus WH6501 to iron grown with $10^{-8} \mathrm{M} \mathrm{Fe}$ (A) $10^{-7} \mathrm{M} \mathrm{Fe}$ (b)

5. Enhancement of dark carbon fixation rates with addition of ammonium for "Experiment $c$ ". 22

6. Standard curve generated from a 2 hour restriction digest of Lambda DNA with HindIII

7. Standard curve generated by a 2 hour restriction digest of plasmid pBR332 with Alu1.

8. A 1\% agarose gel containing DNA from Synechococcus spp. cut with restriction enzymes EcoRI, HindIII and PstI 


\section{CHAPTER I}

\section{INTRODUCTION}

The recent hypothesis that iron flux to the open ocean from transport of aeolian-borne particulate dust controls primary productivity in these regions (Moore and others 1984) has generated a keen interest in the role of iron in controlling productivity in the world's oceans. Duce (1986) estimates that $95 \%$ of the iron available for phytoplankton growth comes from this aeolian transport of dust. Continental dust contains approximately $5.6 \% \mathrm{Fe}$ by weight (Moore and others 1984) and estimates for the amount of biologically available Fe from dust range from 1 to $50 \%$ (1\%, (Hodge and others 1978); 10\%, (Moore and others 1984) and 50\%, (Zhuang and others 1990). The biological availability of iron in dust and the biogeochemical cycle of iron in the open ocean are of crucial importance to metabolic processes in cyanobacteria that are heavily dependent on iron nutrition including photosynthesis, nitrogen fixation and nitrate use. Trichodesmium, a main contributor of fixed nitrogen to tropical oceans, and Synechococcus, which accounts for as much as $47 \%$ of oceanic primary productivity (Glover and others 1988) are two marine cyanobacteria that have elevated iron requirements yet are major contributors to primary productivity. Although both of these organisms remain viable during periods of iron deprivation, a flux of iron to the system enhances new productivity by stimulating nitrogen fixation by Trichodesmium and enabling Synechococcus to more efficiently use nitrate at lower light intensities (Rueter and others man.) at which they 
often predominate. Waters of the North Pacific, the Equatorial Pacific and the Antarctic Oceans contain excess surface nitrate concentrations and only a low biomass. Based on low iron concentrations of $<0.1 \mathrm{nM}$ and increased growth following iron enrichments, Martin and Fitzwater (1988) and Martin and Gordon (1988) hypothesized that the high nitrate, low biomass conditions result from a lack of dust transport. Martin (1990) also generated vigorous debate by suggesting that iron additions to these regions could possibly ameliorate the consequences of increased atmospheric $\mathrm{CO}_{2}$ by increasing primary productivity and creating oceanic carbon sinks.

Iron is an essential nutrient for cyanobacterial growth and is potentially growth limiting in natural environments (Carr and Wyman 1987). Iron availability is limited due to its low solubility in oxic oceanic surface waters where ferrous iron is rapidly oxidized to ferric iron and results in insoluble iron hydroxides. This precipitate is rapidly transported to deeper water and sediments producing iron concentrations in the euphotic zone that often are nearly analytically undetectable. Because the source of iron differs from other major nutrients such as nitrate and phosphorus that are resupplied to the surface waters through advection, autotrophic organisms in the euphotic zone are posed with the perpetual problem of meeting cellular demands for iron (Boyer and others 1987). Additions of iron as FeEDTA and Saharan dust to iron-limited cultures of Synechococcus and natural samples of Trichodesmium resulted in increased growth rates and changes in several physiological parameters (Rueter and Unsworth 1991).

Phytoplankton have a crucial cellular iron requirement to synthesize the many iron-containing compounds that serve major physiological 
functions including photosynthesis, respiration, nitrogen assimilation and pigment synthesis (Sandmann and Malkin 1983). In photosynthesis, iron is vital to iron-containing proteins involved in electron transport including cytochrome b6-f, ferredoxin and non-heme Fe proteins. Iron is vital to nitrate metabolism since the iron-containing protein ferredoxin serves as the electron donor for nitrate and nitrite reductases in the cyanobacteria (Hardie and others 1983). Although iron is not contained in chlorophyll and phycobilin pigments, it is required for their synthesis. These requirements for cyanobacterial physiology combined with a limited bioavailability of iron in the natural environment raises several questions concerning the effect of iron limitation on cyanobacterial physiology. What are the physiological consequences of iron limitation in cyanobacteria? How do cyanobacteria take up iron? How does iron interact with other nutrients such as nitrogen? This thesis builds on previous work focusing on marine cyanobacteria to address these questions.

What are the physiological consequences of Fe limitation in cyanobacteria?

Iron limitation results in a myriad of deleterious effects on the two major energy demanding systems: carbon and nitrogen metabolism. Its importance to biochemical pathways is displayed by cellular response to periods of iron starvation during which ferredoxin, the cytochrome b6-f complex and all PSI and PSII iron-containing redox protein concentrations are reduced and photosynthetic electron flow is less efficient (Sandmann and Malkin 1983; Laudenbach and others 1988). Iron stress interferes with the 
transfer efficiency of the thylakoid ultrastructure, causing a less than optimal function of the photosynthetic apparatus (Guikema and Sherman 1984). In green algae this results in a bioenergetic limitation which reduces the rate of photosynthesis and nitrogen metabolism (Rueter and Ades 1987).

Cyanobacterial cells under iron stress reduce their iron requirement by replacing ferredoxin as the physiological electron donor with Flavodoxin, which contains no iron(Flores and others 1983; Jones thesis). Under periods of iron stress cyanobacteria can also decrease iron-requiring components such as enzymes involved in nitrogen metabolism and photosynthetic membrane proteins. Biochemical and physiological components may be optimized by various light levels or growth on $\mathrm{N}_{2}$ or $\mathrm{NO}_{3}$ vs $\mathrm{NH}_{4}$.

Iron uptake by marine cyanobacteria: How do they get it?

Duce (1986) estimates that $95 \%$ of the iron that is available for phytoplankton growth in the open ocean is derived from aeolian borne particulate dust. Since only a small percentage of the iron in this dust becomes biologically available to phytoplankton, dust input has been hypothesized to control primary productivity in some regions (Moore and others 1984). In both cultures of Synechococcus and natural samples of Trichodesmium, addition of iron as FeEDTA and as Saharan dust resulted in increased growth rate and pigment synthesis. Some cyanobacteria excrete iron binding compounds called siderophores during iron limiting conditions that are involved in the solubilization and transport of ferric iron into the cell (Boyer and others 1987). Neither of these marine species tested seems to produce extracellular siderophores, therefore other mechanisms must be 
important. Microscopic examination of Trichodesmium to which dust particles had been added revealed that the colonies readily adsorbed dust particles. With Synechococcus however, no attachment of dust to the cell surface was observed by microscopic examination. Recent success in cyanobacterial molecular techniques such as the isolation of structural genes for ferredoxin and another iron regulated protein (irpA) (Reddy and others 1988) are evidence that molecular genetics offers possibilities for obtaining important information on the little-understood mechanisms of iron uptake and regulation in these organisms.

\section{How does iron interact with nitrogen?}

Nitrogen is one of the most important macro-nutrients constituting 49\% (proteins, pigments and nucleic acids) of the dry weight of a cyanobacterial cell (Carr and Wyman 1987). Because iron-containing proteins play a crucial role in energy transfer and nitrogen metabolism, iron-limitation results in impaired energetics and nitrogen metabolism. The interaction between iron and nitrogen is important for nitrogen transformations in the water column. For example the nitrogenase enzyme, which catalyses $\mathrm{N}_{2}$ fixation has a high iron requirement (28-36 atoms per complex). Organisms relying on nitrate for photoautotrophic growth require more iron than those growing on ammonium (Rueter and Ades 1987). Dependence on nitrate or $\mathrm{N}_{2}$ verses ammonium for growth determines the ratio of "new" to "recycled" production. Iron-nitrogen interaction identifies the water column dynamics of oceanic regions and influences the phytoplankton community structure. In low iron or iron-limited environments Synechococcus and 
Trichodesmium are able to optimize biochemical and physiological components; this optimization may relieve them of their dependence on recycled nitrogen (ammonium) creating an increase in "new" productivity (nitrate). Measured changes in the ratio of new to recycled productivity indicates changes in water column properties (Platt and Sathyendranath 1988). Increased use of $\mathrm{N}_{2}$ or $\mathrm{NO}_{3}$ linked to of iron input to the system would offer strong evidence supporting the key role of cyanobacteria in carbon and nitrogen metabolism and energy transfer in the water column.

The goal of this thesis is to determine the effect of iron nutrition on cyanobacterial physiology and to define or hypothesize what regulates these changes. This includes the effects of iron on photosynthetic and nitrogen assimilation pathways. Chapter II presents data on the physiological and biochemical changes observed for several strains of marine Synechococcus following iron addition. Chapter III follows with physiological and biochemical analyses of the role of iron nutrition in regulating nitrate assimilation. A suggested method to be used as an indicator of iron limitation in a natural population is also presented. Chapter IV concentrates on iron regulation at the genetic level focusing primarily on freshwater species due to the ease in manipulation of such species as Synechococcus PCC7942. Chapter V offers a summary and conclusion of the experimental work. The desired outcome is a clarification of the interaction between light, iron and nitrogen assimilation through an integration of the analysis and understanding of the biochemical, physiological and genetic response of these organisms. 


\section{CHAPTER II}

\section{INCREASED PIGMENT SYNTHESIS IN CULTURES AND NATURAL SAMPLES OF CYANOBACTERIA DUE TO IRON ADDITIONS}

\section{INTRODUCTION}

Iron is important to the catalysis of biochemical reactions involving photosynthesis, respiration and nitrogen assimilation in cyanobacteria. Iron acts as an ideal electron carrier in the reactions because there is a large variation in redox potential between ferrous and ferric compounds of iron. The steady state effects of iron limitation on fundamental metabolic pathways are indicated by decreased pigment concentrations and changes in the photosynthetic ultrastructure (disruption of the thylakoid membrane) which result in an overall decrease in photosynthetic efficiency. These effects were discussed in the preceding chapter. Iron enrichment of iron limited cultures and natural populations of cyanobacteria has been shown to stimulate carbon fixation, pigment and protein synthesis and growth rate (Rueter and Unsworth 1991; Rueter and Ades 1987). This stimulation by iron or recovery from iron limitation requires a coordinated uptake of iron and incorporation into proteins, which can happen only as fast as protein synthesis is taking place. Thus physiological responses to iron addition such as increased carbon fixation are a function of initial growth rate. The results of this study show that chlorophyll and accessory pigments (phycoerythrin) are synthesized more rapidly than the overall physiological response of the cell to iron. This 
rapid response of pigment synthesis to iron addition is important as an indicator of iron limitation in cultures and natural populations. Increased pigment synthesis as a response to iron addition is especially important as an estimation of primary productivity measured from remote sensing of ocean color (Platt and Sathyendranath 1988). Algorithims for estimating oceanic primary productivity are being developed based on satellite measurement of pigment distribution in oceanic surface waters. Understanding the effects of iron on the rapid response of chlorophyll and phycobilin synthesis is perhaps the first step in elucidating how cyanobacteria efficiently optimize iron use to support iron-requiring biochemical reactions. The activity of the Fe-requiring enzyme that catalyses the synthesis of protochlorophyllide from $\mathrm{Mg}$ protophorphyrin IX monomethyl ester ( $\mathrm{Mg}$-Proto $\mathrm{Me}$ ) is inhibited by ironlimitation causing an accumulation of the intermediate $\mathrm{Mg}$-Proto(Me) in the tetrapyrrole biosynthetic pathway (Spiller and others 1982). This accumulation of $\mathrm{Fe}$ - and $\mathrm{Mg}$-containing tetrapyrroles inhibits the synthesis of ALA ( $\partial$-aminolevulinic acid). Iron deficient cells also exhibit a decrease in heme synthesis which possibly explains a decrease in phycobilin synthesis observed in iron-limited cyanobacterial cells. In barley, heme and chlorophyll synthesis share a common ALA pool and a decrease in iron availability would therefore interfere with the synthesis of $\mathrm{Chl}$-a and phycobilin pigments (Chereskin and Castelfranco 1982). This study measured the increase in Chl-a, phycobiliproteins and ALA in marine Synechococcus spp. and Trichodesmium two strains of cyanobacteria that are important in open ocean productivity. 


\section{MATERIALS AND METHODS}

Synechococcus WH7803, WH6501, and WH8018 were obtained from the Center for the Culture of Marine Phytoplankton, Bigelow Laboratory for Ocean Sciences. Cultures were grown in 1-liter or 2-L polycarbonate bottles at $25^{\circ} \mathrm{C}$ with cool-white fluorescent bulbs providing continuous illumination at 50-70 $\mu \mathrm{mol}$ photons $\mathrm{m}^{-2} \mathrm{~s}^{-1}$. Cultures were grown in AQUIL medium (Morel and others 1979). Iron was added to the medium in total concentrations from $10^{-9}$ to $10^{-6} \mathrm{M}$. Cell density was monitored ever other day after inoculation using a Coulter Counter (Model $2907 \mathrm{ZBI}$ ). Cultures were transferred into new medium with the corresponding iron concentration at least three times; a one-fifth inoculum each time allowed the cells to adapt and go through at least six divisions.

Pigment and protein concentrations were measured as before (Rueter and Unsworth 1991). Phycobilin concentrations were calculated using an equation correcting for spectral overlaps of the pigments (Siegelman and Kycia 1978). We calculated the phycourobilin from measured absorption maxima by assuming the same tabulated absorption coefficient for PE. Chl-a was measured fluorometrically on homogenized cell material extracted overnight in $90 \%$ acetone (Parsons and others 1984). ALA on Synechococcus cultures was measured by the modified method of Schneegurt and Beale (1988). $400 \mathrm{~mL}$ of culture was filtered onto Whatman GF/F filters and the filter was ground in $1.5 \mathrm{~mL}$ of homogenization buffer. Microcentrifuge tubes containing the sample were centrifuged at high speed for 10 minutes in an Eppendorf centrifuge. $50 \mu \mathrm{L}$ of supernatant from the homogenized sample was added to $200 \mu \mathrm{L}$ of reaction buffer and tubes were then incubated in two 
seperate batches at $30^{\circ} \mathrm{C}$ and room temperature for 30 minutes. After the 30 minute incubation $12.5 \mu \mathrm{L}$ of $100 \% \mathrm{w} / \mathrm{v}$ TCA was added to terminate the reaction. $200 \mu \mathrm{L}$ of sample was then added to glass test tubes and the tubes cooled on ice for 10 minutes. An equal volume of freshly prepared Ehrlich$\mathrm{Hg}$ reagent was added, mixed gently and absorbance was measured on a spectrophotometer at $552 \mathrm{~nm}$. Time zero and 30 minute incubations of an ALA standard curve comprised of $0,5,10$ and $30 \mu \mathrm{M}$ concentrations were also measured. ALA formation rate was calculated by plotting the sample absorbance readings at time zero and 30 minute against the standard curve at time zero and 30 minute incubations. A more complete description of all culture and analytical methods are provided in Appendix A and B.

\section{RESULTS}

From previous experiments carried out on cultures grown at different iron concentrations we determined that $10^{-6} \mathrm{M}$ iron cultures grew faster and reached stationary phase after about 6 days and the slower growing ironlimited cultures continued active growth for up to 11 days. Based on this cells were harvested at 6 days so that all cultures would be in active growth phase. Cell density was a function of the initial iron concentration of the medium for all three strains of Synechococcus (Figure 1). Both total cellular protein and cell iron concentration varied with total iron concentration. (Figure 2). The effect of iron on cell number and protein was similar for the three clones, indicating that protein is a conservative parameter of cellular response. Chl-a and phycobilin concentrations were much more flexible characteristics of the cultures than total cell number and protein. A cell can remain viable and 
have extremely low pigment concentrations. For the three clones in the study Chl-a $(\mu \mathrm{g} / \mathrm{ml})$ showed an increase with iron that was greater than or equal to the variation in cell number (Figure 3).

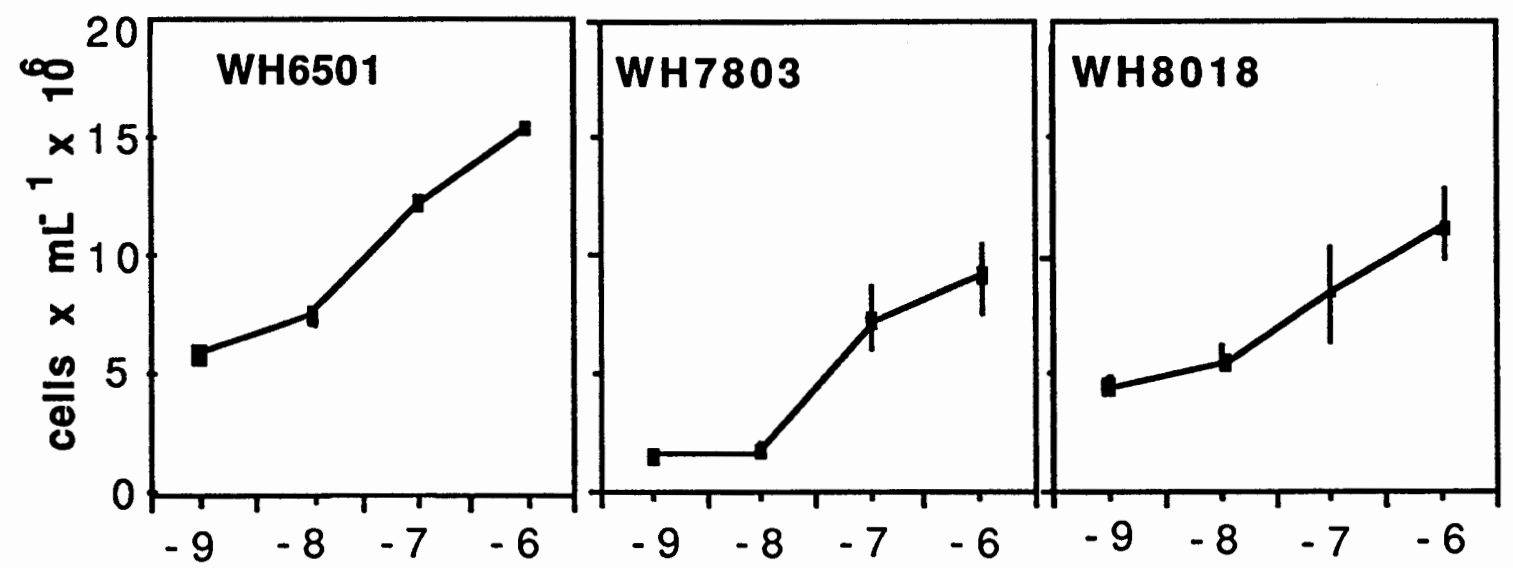

Figure 1. Growth response of Synechococcus strains WH6501, WH7803 and WH8018 to a range of iron concentrations $\left(10^{-9} \mathrm{M}\right.$ $\mathrm{Fe}-10^{-6} \mathrm{M} \mathrm{Fe}$ ).
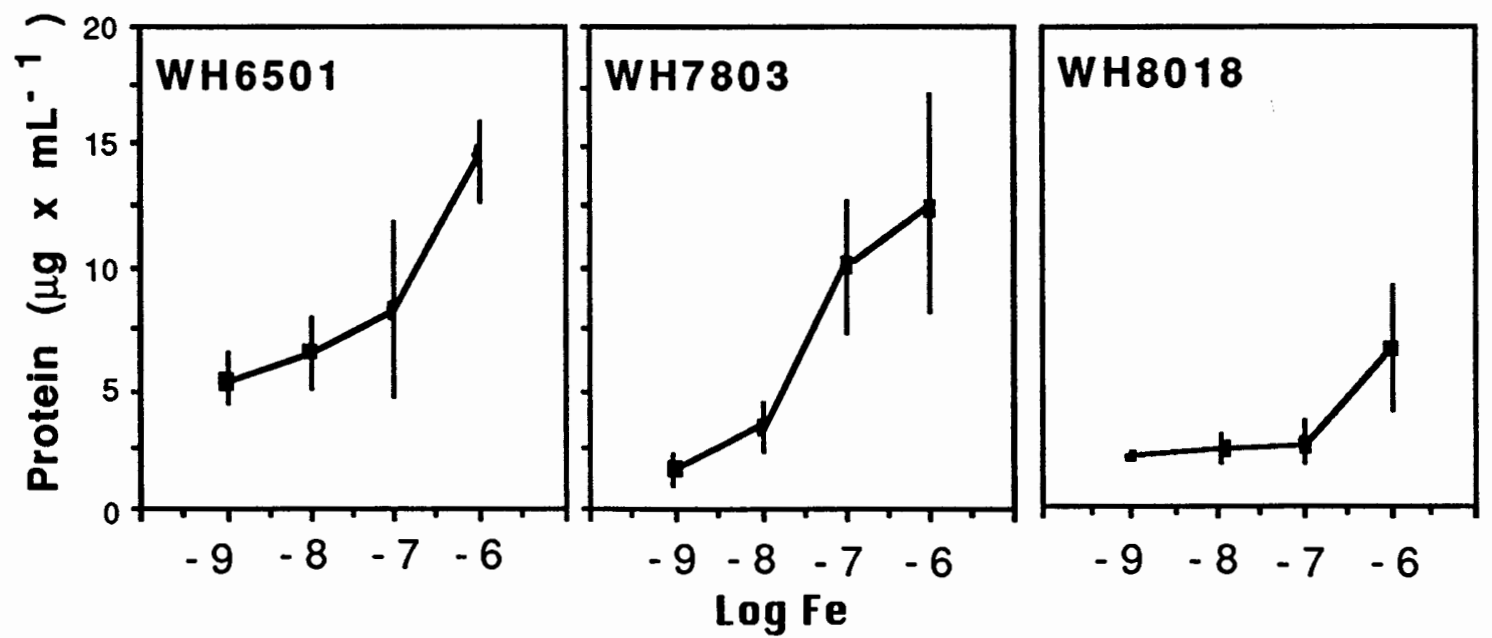

Figure 2. Measurement of total cellular protein per milliliter of culture for the three Synechococcus strains studied. Protein increases with increasing iron concentration. 

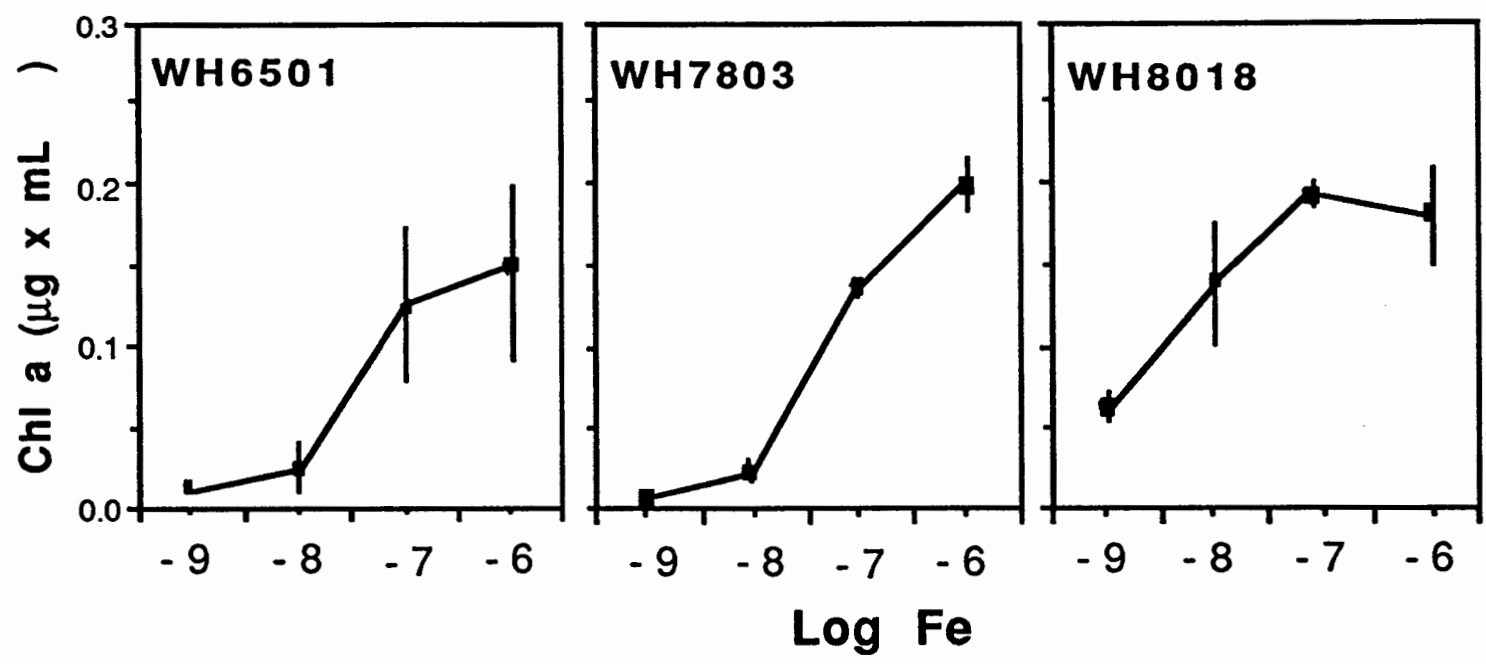

Figure 3. Chl-a concentration for the three Synechococcus strains sampled. Chl-a concentration increased with an increase in iron.

Phycobiliprotein pigment (PBP) content can make up a substantial portion of the cell protein (15-25\%) and varies among different species in the relative composition of phycoerythrin (PE), phycocyanin (PC), and allophycocyanin (APC). For marine Synechococcus, phycoerythrin occurs in the highest ratio. Total PBP concentration increased with iron for all three clones, but each showed a distinct response to Fe availability. For WH6501 PBP increased proportional to protein, maintaining an average PBP: protein ratio of $23 \%$. A relatively constant fraction of that PBP was PE $(43 \% \pm 9 \%)$. WH8018 also had a relatively constant PBP:protein ratio $(24.4 \% \pm 9.6 \%)$, and the ratio of PE:PBP was also similar $(46 \% \pm 1.6 \%)$ for all but the lowest iron concentration in which PE was 59\% of the PBP. In contrast, PBP: protein in WH7803 had a sixfold increase with iron and the relative PE content decreased with increasing iron concentration (Table I). Previous studies using Synechococcus and Trichodesmium to which iron was added as aeolian dust and as FeEDTA 
resulted in increased concentrations of phycoerythrin and Chl-a for both organisms (Rueter and others 1991).

TABLE I

THE EFFECT OF IRON ON PHYCOBILIN CONTENT OF SYNECHOCOCCUS WH7803 AFTER SIX DAYS (THE DATA ARE THE MEAN OF TWO EXPERIMENTS \pm RANGE)

Iron Concentration

$10^{-9} \mathrm{M} \mathrm{Fe}$

$10^{-8} \mathrm{M} \mathrm{Fe}$

$10^{-7} \mathrm{M} \mathrm{Fe}$

$10^{-6} \mathrm{M} \mathrm{Fe}$
PBP Content $(\mu \mathrm{g} / \mathrm{mL})$

$0.047 \pm 0.003$

$0.160 \pm 0.017$

$0.895 \pm 0.075$

$2.245 \pm 0.205$

\% Phycoerythrin

39

47

30

24

Cultures of marine Synechococcus WH6501 were grown at several different iron concentrations to examine the effect of iron on ALA synthesis rate. Chl-a, protein, PBP and cell counts were measured daily on these cultures to ensure that cells harvested were still in exponential growth. Cultures were spiked with 10 times more iron relative to the initial iron concentration and incubated from 12 to 20 hours. ALA synthesis was measured at 4 hour intervals commencing after 12 hours. Cultures grown at $5 \times 10^{-8} \mathrm{M} \mathrm{Fe}$ and spiked to $5 \times 10^{-7} \mathrm{Fe}$ prior to the 12 hour incubation had a higher rate of ALA synthesis 17 hours after the addition of iron (Table II). In two similar shipboard experiments $10^{-7} \mathrm{M}$ FeEDTA added to natural samples ofTrichodesmium produced an increase in ALA synthesis rate by 17 and $42 \%$ of the control after a 3 hour incubation. Natural samples of Trichodesmium 
to which FeEDTA and dust were added had higher concentrations of Chl-a and PE with increased iron concentration (Table III).

\section{TABLE II}

INCREASE IN ALA SYNTHESIS RATE IN SYNECHOCOCCUS WH6501 CULTURES PREINCUBATED WITH $5 \times 10^{-7} \mathrm{M}$ Fe FOR 16 HOURS

\begin{tabular}{c|c}
\multicolumn{2}{c}{ ALA synthesis rate } \\
\hline No iron added & $5 \times 10^{-7} \mathrm{M} \mathrm{Fe}$ \\
\hline $3.0 \mu \mathrm{mol} / \mathrm{h}$ & $3.9 \mu \mathrm{mol} / \mathrm{h}$ \\
\hline
\end{tabular}

TABLE III

SHORT TERM REPONSE (13 HOURS) OF Chl-A AND PHYCOERYTHRIN SYNTHESIS IN TRICHODESMIUM TO ADDED IRON

\begin{tabular}{ccc} 
Treatment & $\begin{array}{c}\text { Chl-a } \\
(\mu \mathrm{g} / \mathrm{ml})\end{array}$ & $\begin{array}{c}\text { PE } \\
\text { (Relative } \\
\text { fluoresence units) }\end{array}$ \\
\hline$+20 \mathrm{nM} \mathrm{Fe}$ & .065 & 1.4 \\
$+100 \mathrm{nM} \mathrm{Fe}$ & .073 & 1.4 \\
$+500 \mathrm{nM} \mathrm{Fe}$ & .080 & 2.0 \\
$+1 \mathrm{mg}$ dust & --- & 2.2 \\
$+5 \mathrm{mg}$ dust & .058 & 3.0 \\
$+25 \mathrm{mg}$ dust & .067 & 4.4 \\
& & \\
& &
\end{tabular}

The range of responses of the Synechococcus cultures to iron was much greater for Chl-a and phycobilin pigment proteins than it was for cell number 
or protein. Cell number was 2.5-7.7 times higher from lowest to highest iron concentration for these strains. Protein increased from 3-7.8 times, and Chl-a increased from 2.8-28 times. The PBP content was similar to protein. These relative changes in cell composition are much lower than the changes in iron availability which ranged from $10^{-9}$ to $10^{-6} \mathrm{M} \mathrm{Fe}$ (a 1000-fold range). This range drops to 500 if iron contamination estimates in AQUIL (Anderson and Morel 1982) are taken into account. Cellular response to iron for the measured parameters was less than linear to available iron and cellular iron. A regression of cell parameters against total iron concentration results in functions that are roughly the cube root of iron cocentration for cell density and total protein and roughly the square root of iron concentration for pigments and productivity rates. This suggests that iron-limited cells maintain a higher iron use efficiency resulting in only slightly diminished growth capacities by conserving crucial iron containing components whereas increased iron availability has diminishing marginal returns in terms of biomass, pigments and productivity. Although the wide range and rapid response of Chl-a to iron addition is a good indicator of iron limitation it is not a good choice for use as a normalization parameter since iron availability is not consistent either in culture or in the natural environment.

Although the results are preliminary, a definite stimulation of ALA synthesis following incubation with increased iron concentrations was measured for Synechococcus cultures and natural samples of Trichodesmium. This increase in ALA synthesis, an increase in Chl-a per cell in the first 12-24 hours after iron addition and an increase in PBP concentration with added iron shows that pigment synthesis is the first 
parameter to respond to iron addition. This emphasizes the importance of considering iron in algorithims for oceanic primary productivity via satellite sensing based on pigment absorbance. 


\section{CHAPTER III}

\section{ENHANCEMENT OF DARK CARBON FIXATION IN IRON-LIMITED CULTURES OF SYNECHOCOCCUS WH6501}

\section{INTRODUCTION}

The inorganic nitrogen assimilatory pathway involving the reduction of nitrate to nitrite is energetically expensive requiring almost $50 \%$ as much of the cells metabolic energy as carbon fixation (Syrett 1981; Turpin 1991). The formation of glutamate from this assimilatory process requires ATP and reductant generated from photosynthesis thus tightly linking light to nitrogen metabolism. Iron too has a vital role in nitrate metabolism since the iron-containing protein ferredoxin serves as the electron donor for nitrate and nitrite reductase in the cyanobacteria and both of these reductases require iron as a structural component (Peschek 1979). Nitrate and nitrite reductase, in addition to their dependence on reduced ferredoxin, are intimately associated with photosynthetic membranes emphasizing the link between nitrate reduction and reductive energy generated by photosynthesis (Flores and others 1983). Even though these processes are all inter-related, it is important to assess whether an algal population is limited by a single factor or by a combination of light, nitrogen and/or iron. Vincent (1981) and Pick (1987) have successfully identified nitrogen and phosphorus limitation of algal populations by monitoring increases in ${ }^{14} \mathrm{C}$ fixation rates with added ammonium of phosphorus. The rapid uptake and assimilation of nitrate, 
phosphate or ammonium into amino acids or sugar-phosphate metabolites and the resulting availability of these metabolites creates optimal biosynthetic machinery which produces accelerated rates of photosynthetic carbon fixation. Stimulation by iron or recovery from iron limitation differs from this due to its coupling with protein synthesis. There are no pools of apo-proteins which iron insertion would make metabolically active. This chapter presents a method for assessing iron limitation based on an enhanced rate of dark carbon fixation in nitrate grown, iron limited Synechococcus cultures with ammonium chloride added to a $5 \mu \mathrm{M}$ concentration.

\section{MATERIALS AND METHODS}

Cultures of Synechococcus WH6501 were grown in AQUIL medium as previously described in this thesis. Iron from a $10^{-2} \mathrm{M}$ FeEDTA stock was added to give final concentrations of $10^{-8} \mathrm{M} \mathrm{Fe}$ and $10^{-7} \mathrm{M} \mathrm{Fe}$. Cultures were transferred into fresh media at $10^{-8}$ and $10^{-7} \mathrm{M}$ Fe concentrations every six days to insure that the cells were not nitrogen limited and remained in active growth phase (Rueter and Unsworth 1991). At least three of these transfers with a one-fifth volume inoculum $(100 \mathrm{ml})$ were carried out to allow the cells to go through a minimum of six divisions and adapt to the iron content of the medium.

Following the initial inoculation, cell number was measured daily by microscopic counts. Total protein, $\mathrm{Chl}$-a concentration and $\mathrm{NO}_{3}$ were measured as previously described (Rueter and Unsworth 1991; Rueter and Ades 1987). Carbon fixation rate was estimated by the uptake of ${ }^{14} \mathrm{C}$. Cultures were spiked with $\mathrm{NaH}^{14} \mathrm{CO}_{3}$ that had been passed through a Chelex-100 
column to remove contaminating trace metals. $15-\mathrm{mL}$ aliquots in Oakridge polycarbonate tubes were spiked with $5 \mathrm{mM}$ ammonium chloride to a final concentration of $5 \mu \mathrm{M}$ and replicate samples for each iron concentration were incubated for three hours both in $70 \mu \mathrm{mol}$ photons $\mathrm{m}^{-2} \mathrm{~s}^{-1}$ and in foil wrapped tubes for dark incubation. For use as controls, untreated aliquots from both iron concentrations were incubated under the same conditions. Following a three-hour incubation, samples were filtered onto $0.2 \mu \mathrm{m}$ Nuclepore filters, the filters dried and uptake rates measured with a liquid scintillation counter. Culture and analytical methods are more completely described in Appendix A and $B$.

\section{RESULTS}

Cultures were sampled daily over a 4-5 day period for cell number, total protein and Chl-a concentration. The $10^{-7} \mathrm{M}$ Fe cultures had higher concenrations of total protein and Chl-a (Table IV) and a faster growth rate than the iron limited $\left(10^{-8} \mathrm{M} \mathrm{Fe}\right)$ cultures (Figure 4). Amounts of the measured parameters for each iron concentration varied between experiments a, b and c since cultures for each experiment were at slightly different points in their growth curve when sampled. All cultures, however, were sampled during active growth phase. Cellular responses to these parameters correspond to previous results obtained with Synechococcus WH6501 grown at the same iron concentrations (Rueter and Unsworth 1991). During the sampling period, growth rates at each of the iron concentrations never led to the depletion of nitrate from the medium. Light-incubated $10^{-7}$ $\mathrm{M}$ Fe cells had higher ${ }^{14} \mathrm{C}$ fixation rates than $10^{-8} \mathrm{M}$ Fe light-incubated cells, 
but normalization of these rates to Chl-a content showed uptake rates for $10^{-7}$ $\mathrm{M}$ Fe cells to be only $62-83 \%$ of the iron-limited $\left(10^{-8}\right)$ culture (Table V).

\section{TABLE IV}

CELLULAR PARAMETERS AND DARK CARBON FIXATION RATE FOR FOUR EXPERIMENTS. "EXPERIMENT A" WAS MEASURED AFTER FOUR DAYS AND B,C AND D WERE MEASURED AFTER 5 DAYS

\begin{tabular}{cccccc} 
Experiment & Fe conc. & $\begin{array}{c}\text { Protein } \\
(\mu \mathrm{g} / \mathrm{mL})\end{array}$ & $\begin{array}{c}\text { Chl-a } \\
(\mu \mathrm{g} / \mathrm{mL})\end{array}$ & \multicolumn{2}{c}{ dark ${ }^{14} \mathrm{C}$ fix } \\
$+\mathrm{NH}_{4}$ & $-\mathrm{NH}_{4}$ \\
\hline \multirow{2}{*}{$\mathrm{a}$} & $10^{-8}$ & 6.9 & .088 & 1074 & 720 \\
& $10^{-7}$ & 14.4 & .312 & 453 & 481 \\
$\mathrm{~b}$ & $10^{-8}$ & 4.8 & .088 & 198 & 162 \\
& $10^{-7}$ & 8.7 & .163 & 122 & 185 \\
$\mathrm{C}$ & $10^{-8}$ & 12.6 & .195 & 908 & 605 \\
& $10^{-7}$ & 17.4 & .346 & 588 & 651 \\
& & & & & \\
\hline $\mathrm{d}$ & $10^{-7}$ & 12.0 & .130 & 150 & 175 \\
& $5 \times 10^{-7}$ & 15.0 & .150 & 170 & 166 \\
& & & & &
\end{tabular}

This suggests that the iron limited cells maintained an efficient energy metabolism in the light and that reduced photosynthetic capacity is not solely responsible for lowered nitrate reduction. Ammonium addition to both low and high Fe cultures prior to light incubation produced only a slight effect on the carbon fixation rate (a mean increase of $1.3 \% \pm 3.5 \%$ ). Dark carbon fixation rate in these cultures showed two interesting features. First, there was a significant dark carbon fixation rate which ranged from $1.3-11 \%$ with a mean of $6.8 \%$ of the light carbon fixation rate. Second, the addition of ammonium prior to incubation resulted in an enhanced dark carbon fixation rate. This 
enhancement, calculated as $\left[\left(+\mathrm{NH}_{4} / \mathrm{NH}_{4}\right)-1\right] \times 100 \%$, ranged from $22-50 \%$ for $10^{-8} \mathrm{M}$ Fe cultures spiked with ammonium compared to untreated cells. No enhancement was observed for $10^{-7} \mathrm{M}$ Fe samples (Figure 5).
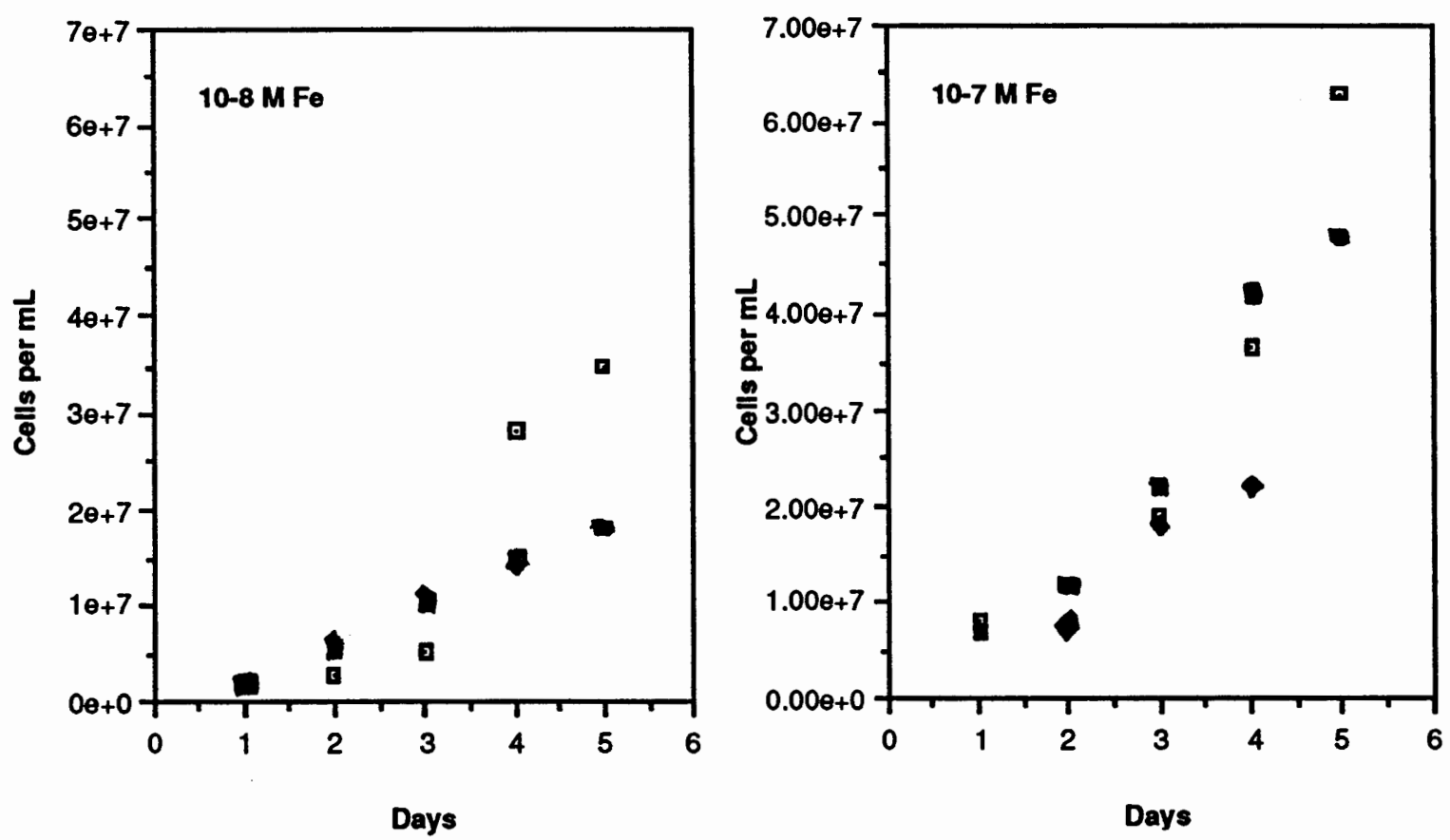

Figure 4. Growth response of Synechoccuccs WH6501 to iron grown with $10^{-8} \mathrm{M} \mathrm{Fe}(\mathrm{A}) 10^{-7} \mathrm{M} \mathrm{Fe}(\mathrm{b})$. The mean value for three separate experiments is shown; $a=a, a=b, \bullet=c$.

\section{TABLE V}

CARBON FIXATION RATE FOR CELLS GROWN IN THE LIGHT WITH NO AMMONIUM ADDED. RELATIVE CARBON FIXATION GIVEN IN COUNTS PER MINUTE PER MICROGRAM Chl- $\underline{A}$

\begin{tabular}{cccc} 
Experiment & \multicolumn{2}{c}{$\mathrm{CPM} / \mu \mathrm{gChl}-\underline{\mathrm{a}}$} & $\begin{array}{c}\text { Ratio } \\
10^{-8}\end{array}$ \\
\hline $\mathrm{a}$ & $1.2 \times 10^{-7}$ & $1.4 \times 10^{5}$ & \\
$\mathrm{~b}$ & $1.6 \times 10^{4}$ & $2.0 \times 10^{4}$ & 0.83 \\
$\mathrm{c}$ & $1.6 \times 10^{4}$ & $2.6 \times 10^{4}$ & 0.80 \\
\hline
\end{tabular}




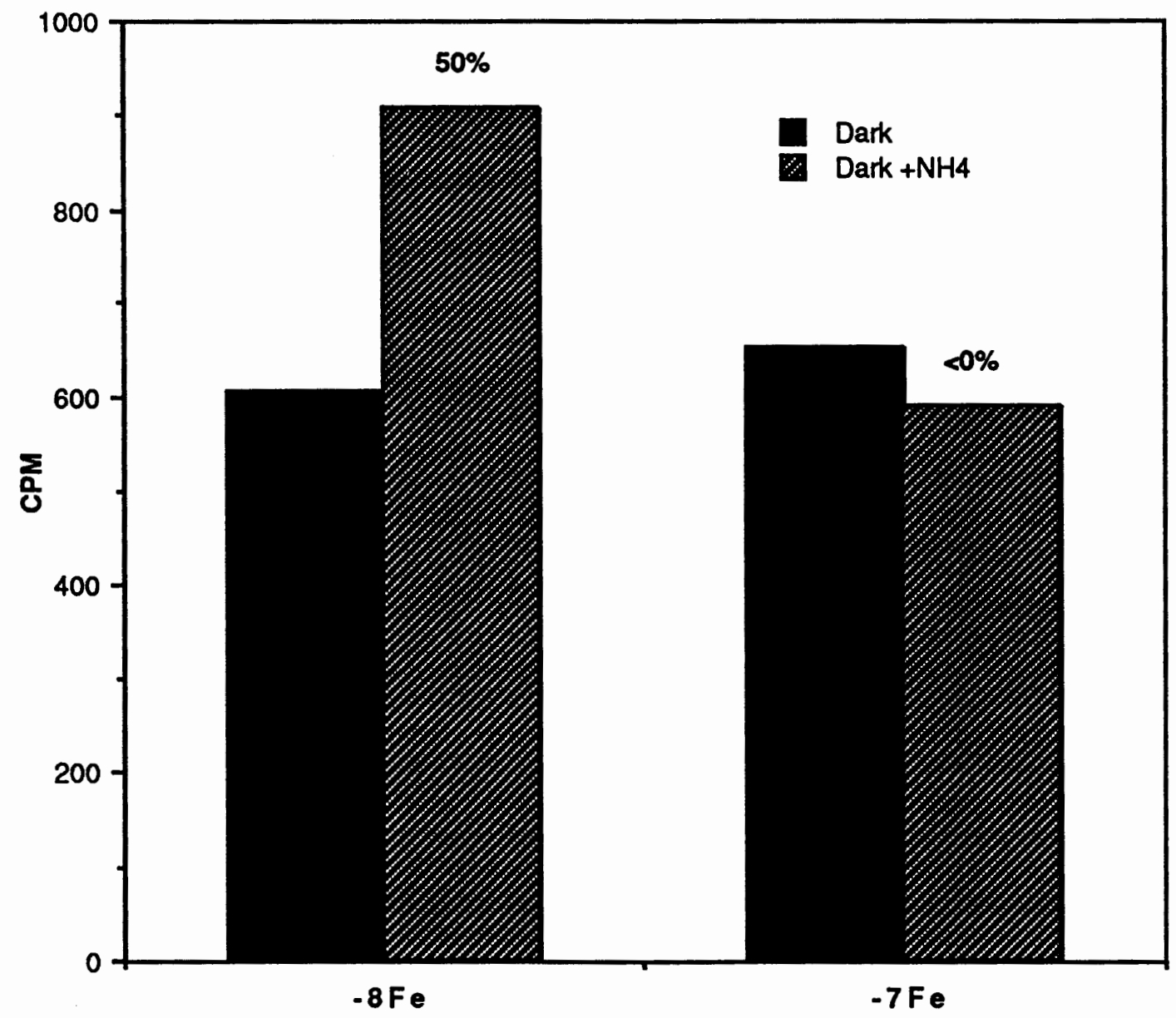

Figure 5. Enhancement of dark carbon fixation rates with addition of ammonium for "Experiment c". 
In a fourth experiment, one large culture was grown through the same transfer regime at $10^{-7} \mathrm{M} \mathrm{Fe}$ and monitored in the same manner as above. Twenty-four hours prior to assaying for the ammonium effect on dark carbon fixation rate, the culture was split and $5 \times 10^{-7} \mathrm{M} \mathrm{Fe}$ was added to one of the cultures. Protein concentration, Chl-a concentration and CPM (counts per minute)/ $\mu \mathrm{g}$ Chl-a were $25 \%, 15 \%$ and $85 \%$ higher respectively for the $5 \times 10^{-7}$ Fe culture. There was no light or dark enhancement effect on samples with added ammonium (Table IV). This suggests that iron controls growth rate; even though $10^{-7} \mathrm{M}$ Fe cells are "iron-limited" in that they grow better with added iron, there is a physiological difference between these cells and $10^{-8} \mathrm{M}$ Fe grown cells.

\section{DISCUSSION}

In this study and previous work (Rueter and Unsworth 1991) there seems to be a physiological difference between cells grown at $10^{-8} \mathrm{M}$ Fe and $10^{-}$ $7 \mathrm{M} \mathrm{Fe}$. The response of WH6501 cells to restricted iron nutrition $\left(10^{-8} \mathrm{Fe}\right)$ is characterized by slower growth rates, reduced concentrations of $\mathrm{Chl}$ - $\underline{a}$ and protein and lower carbon fixation rates. These results emphasize the crucial roles that iron plays in metabolism and this integrated control makes it impossible to predict whether a cell is iron-limited simply by looking at ratios of these parameters as might be done for nitrogen or phosphorus limitation. We were able to demonstrate that ammonium-dependent dark carbon fixation enhancement is a feature of iron-limited cultures and is not seen in iron-replete cultures. 
We hypothesize that ammonium enhanced dark carbon fixation rates for iron-limited cultures is an effect of the decrease in the cells ability to take up nitrate from the media and to undergo subsequent intracellular reduction of this nitrate to ammonia. Because metabolism is slowed due to iron deficiency, the potential for carbon flux is not realized. Thus, ammonium addition to iron-limited cultures causes an acceleration of amino acid synthesis due to a metabolic energy requirement that is much less than that required for the reduction of nitrate. This establishes that iron nutrition plays a biochemical role in nitrogen assimilation, but it can not be determined from our results what specifically is restricting the reduction of nitrate to ammonia. We offer two possible explanations. First, that iron-limited cells have a low efficiency of energy transfer due to ferredoxin, which requires iron, operating as electron donor. Although nitrogen is available in the medium, the cells are unable to use it effectively. Second, the cellular efficiency of the iron-containing enzyme nitrite reductase, which relies on ferredoxin as its immediate electron donor may be a site for the limitation of nitrate assimilation. Regardless of an individual or collective effect causing this restriction there is insufficient reduction of $\mathrm{NO}_{3}$ and $\mathrm{NO}_{2}$ to match the potential carbon flow to amino acid synthesis.

In addition to the primary uptake of $\mathrm{CO}_{2}$ via the carboxylation of RuBP in the Calvin cycle by cyanobacteria, significant quantities of ${ }^{14} \mathrm{C}$ are incorporated into glutamate, aspartate, alanine and phosphoenyl pyruvate (PEP) (Tabita 1988). The carboxylation of PEP by PEP carboxylase which ultimately results in the flow of carbon to amino acids such as glutamate and aspartate is evidence of an alternative $\mathrm{CO}_{2}$ fixation pathway that is important 
and which significantly complements the Calvin cycle in cyanobacteria (Tabita 1988). The fixation of ${ }^{14} \mathrm{C}$ via this alternative pathway occurs predominately at low light and may be advantageous to cyanobacteria during limiting light conditions by enabling them to preferentially channel carbon to amino acids and bypass the more energy expensive Calvin Cycle.

The ammonium enhancement technique that we are proposing could be a useful assay in supporting the contention that populations of Synechococcus in nitrate rich waters are Fe limited. Knowledge of the iron nutritional status of these populations in turn would indicate whether the cells are contributing to new production or are relying on regenerated ammonium (Wheeler and Kokkinakis 1990) in which case there would be no evidence of ammonium enhancement. 
CHAPTER IV

IRON REGULATION AT THE GENETIC LEVEL: DO CYANOBACTERIA POSSESS A SEQUENCE HOMOLOGOUS TO THE E. COLI FERRIC UPTAKE REGULATION (FUR) GENE?

\section{INTRODUCTION}

Many bacteria, including cyanobacteria have adaptations that allow them to maintain efficient energy harvesting and transduction during periods of iron limitation. The mechanism of regulation of iron uptake and metabolism is well understood in E. coli. During periods of iron starvation they excrete siderophores which are specialized high affinity iron transport systems (Simpson and Neilands 1976) and synthesize membrane proteins that transport iron into the cell. The characterization of five iron transport systems associated with siderophore production in $E$. coli has been the basis for a focus on molecular techniques as a tool for identifying a similar iron regulation mechanism operating in cyanobacteria that might explain their widespread success. The response in $E$. coli involves 26 genes, all of which are derepressed by iron limitation (Schaffer and others 1985). Many freshwater cyanobacteria are known to produce siderophores during periods of iron stress in their natural environment. Likewise then, it would seem that marine cyanobacteria such as Synechococcus spp., that have optimized their cellular iron metabolism and uptake to maintain successful growth rates in a system often limited by iron, light and nutrient availability would posses the same or a similar mechanism. 
This chapter presents work that looked for genes in cyanobacteria that are homologous to the ferric uptake regulation gene (fur) in E. coli. Zetaprobe membrane blot hybridizations containing chromosomal DNA from four different species of cyanobacteria were probed with a $1.1 \mathrm{~kb}$ fragment of the iron-regulated $E$. coli fur gene to determine if a similar gene sequence could be found in cyanobacteria. Three freshwater and one marine strain were selected for their physiological and biochemical characteristics.

Anabaena 7120 fixes nitrogen and produces siderophores. DNA from two other freshwater strains (1 PCC7942 which contains an iron regulated gene (irpA , (Reddy et al. 1988) and produces a hydroxamate siderophore (Scanlan et al. 1989) and 2) PCC6301 which has a close genetic relationship to PCC7942 were compared. A fourth marine form, Synechococcus WH6501, does not fix nitrogen and has no known production of extracellular siderophores but is able to grow efficiently at low light and under conditions of nutrient and iron limitation. DNA from each organism underwent complete digestion with several restriction enzymes and analysis of the Southern hybridizations revealed weak hybridization in Anabaena 7120, and Synechococcus PCC6301 and PCC7942. No band was observed for the DNA from the marine Synechococcus.

\section{MATERIALS AND METHODS}

Cultures of Anacystis nidulans R2 (PCC7942) were obtained from the laboratories of Susan Golden and David Laudenbach. Anacystis nidulans was grown in BG-11 medium (Thiel and others 1989) at $25^{\circ} \mathrm{C}$ under coolwhite fluorescent bulbs. Cultures were inoculated in sterile media that had 
been autoclaved for 20 minutes and bubbled with $1 \% \mathrm{CO}_{2}$ to resolubilize precipitates and then grown in sterile glass Ehrlenmeyer flasks. Cultures of Synechococcus PCC6301 and Anabaena 7120 obtained from John Goldbeck, PSU and William Fish, OGI respectively, were grown in Kratz and Meyers medium also using sterile technique. All three strains received the same irradiance levels and culture vessels were manually agitated daily and periodically checked for bacterial contamination. Synechococcus WH6501 was obtained from the Center for the Culture of Marine Phytoplankton. Cultures were grown as previously described. Chromosomal DNA was prepared from $200-500 \mathrm{~mL}$ to obtain a minimum of $5 \mu \mathrm{g}$ of DNA. DNA from the freshwater species was isolated by the method of Mazur et al. (1980) and DNA was isolated from Synechococcus WH6501 by the methods of Wood and Townsend (1990).

A bacterial stab consisting of the PACYC184 vector with plasmid pMH15 which carries a $2.2 \mathrm{~kb}$ insert in containing the $E$. coli fur gene was provided by Klaus Hantke (University of Tubingen). To identify sequence homology between the fur gene and cyanobacterial DNA, a $1.1 \mathrm{~kb} \mathrm{Accl} / \mathrm{BglI}$ fragment containing the fur gene was used as a hybridization probe. This probe was prepared by a double restriction digest of pMH15 obtained from mini plasmid preps (Maniatis and others 1982) of $5 \mathrm{~mL}$ overnight bacterial cultures. The correct fragment was determined by electrophoresis of the restriction digest on a $1 \%$ LMT (low melting temperature) agarose gel containing ethidium bromide and comparison to Lambda/HindIII and PBR322/Alu size markers (Figures 6 and 7) The correct band was excised from the gel and purified from the agarose using a Prep-a-Gene kit (BioRad). 


\section{Lambda DNA/HindIII marker}

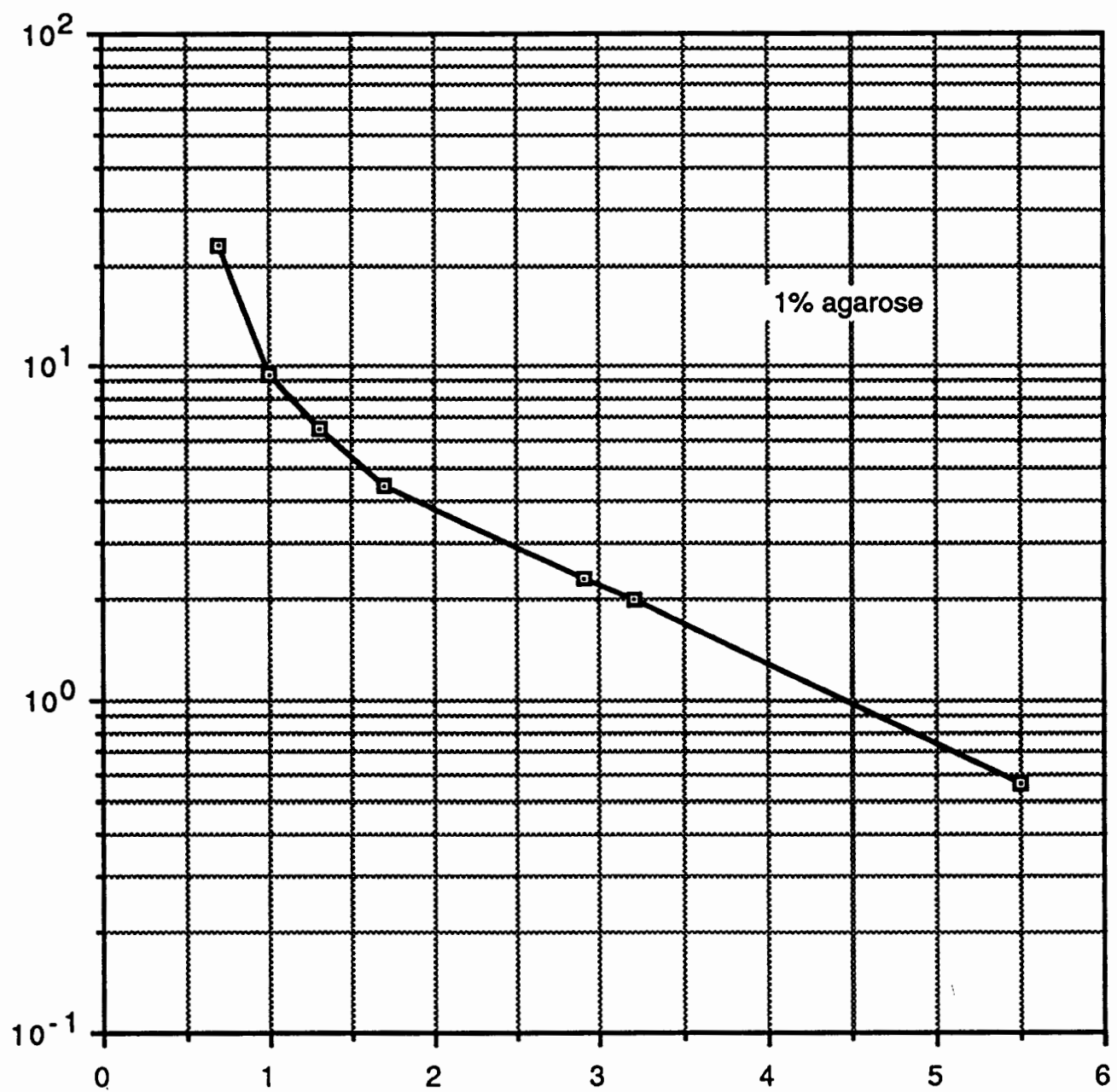

distance migrated $(\mathrm{cm})$

Figure 6. Standard curve generated from a 2 hour restriction digest of Lambda DNA with HindIII. By plotting the distance traveled on the gel for the Acc/Bgl restriction of plasmid pMH15, the $1.1 \mathrm{~kb}$. insert could be identified. 


\section{pBR322/Alul marker}

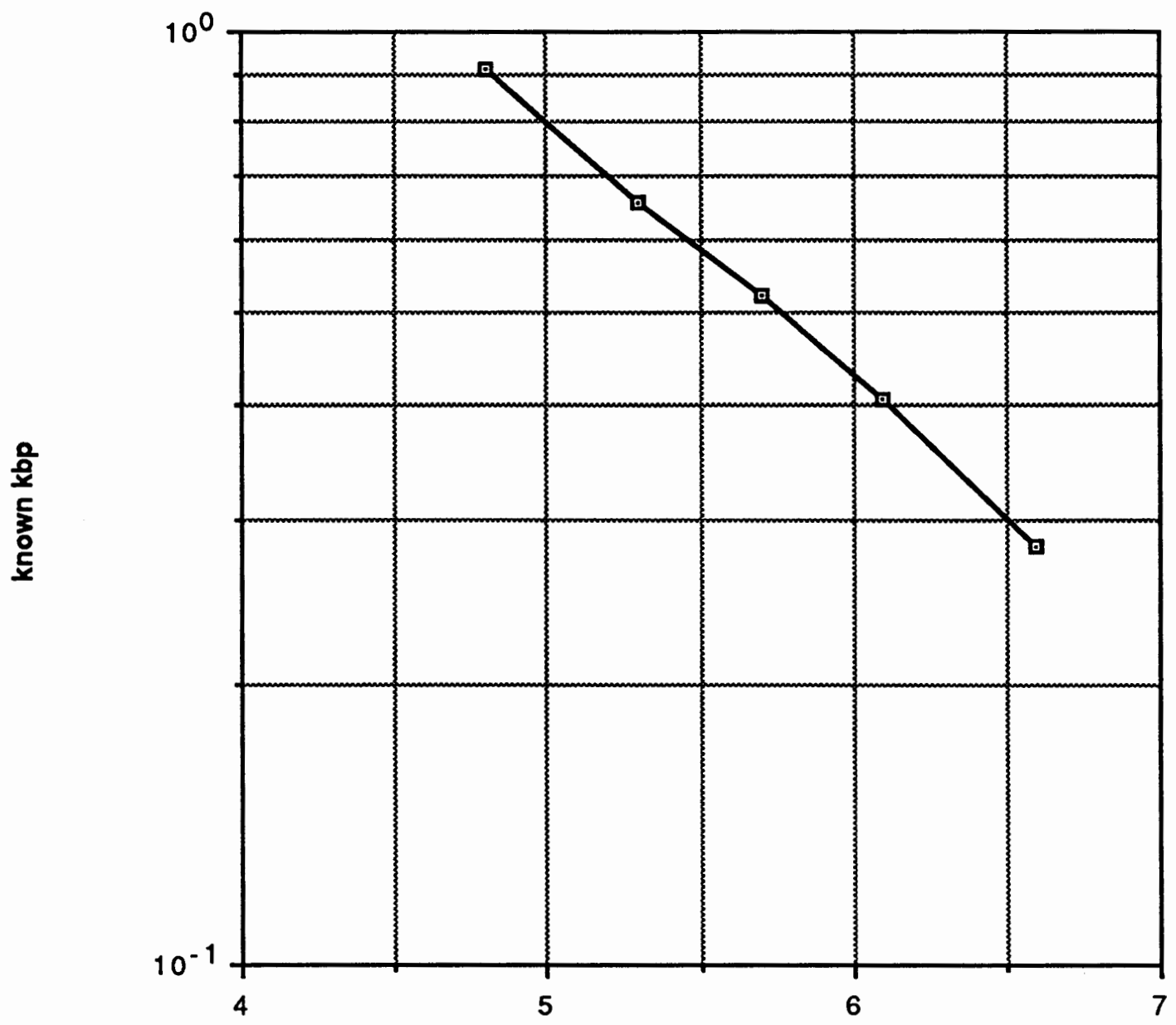

distance migrated $(\mathrm{cm})$

Figure 7. Standard curve generated by a two hour restriction digest of plasmid pBR332 with Alu1. This marker is run with a Lambda/HindIII marker to overlap the smaller kbp regions where the $1.1 \mathrm{kbp}$ insert is located. 
Chromosomal DNA from each species underwent complete digestion with four different restriction enzymes (EcoRI, HindII, HindIII and PstI) in a $50 \mu \mathrm{l}$ volume and $20 \mu \mathrm{l}$ of each sample was added to a $1 \%$ agarose gel (Figure 8). The gel was run at $20 \mathrm{~V}$ for $16-20$ hours and the DNA subsequently transferred onto Zetaprobe membrane (BioRad) using the technique of Southern. The probe was radiolabeled with ${ }^{32} \mathrm{P}$ dCTP using a random priming kit (Boehringer Mannheim). Hybridization of the fur probe to chromosomal DNA digestions was determined by autoradiography. Cassettes containing labeled membrane filters and X-ray film (Kodak) were foil wrapped and placed in a $-70^{\circ} \mathrm{C}$ freezer for 2-3 days. (For a more detailed description of protocols such as prehybridization, hybridization and washing conditions ; see Appendices). The size of the band (in $\mathrm{kb}$ ) was measured by comparison to a pBR322 marker standard run on each side of the sample wells.

\section{RESULTS}

The weak hybridization of the E. coli fur probe to DNA from PCC7942, 6301 and Anabaena 7120 is particularly significant due to the fact that all of these strains produce siderophores at low iron concentrations. In E. coli, the repression of the enzymes that synthesize siderophores are effected by the Fur protein which is in turn coded for by the fur gene. When iron is readily available to the cell the Fur potein binds to iron forming a repressor complex that binds to an "iron box." The binding of this complex to the "iron box" blocks transcription of downstream genes. When intracellular iron concentration is lowered the enzymes are derepressed and siderophores are 


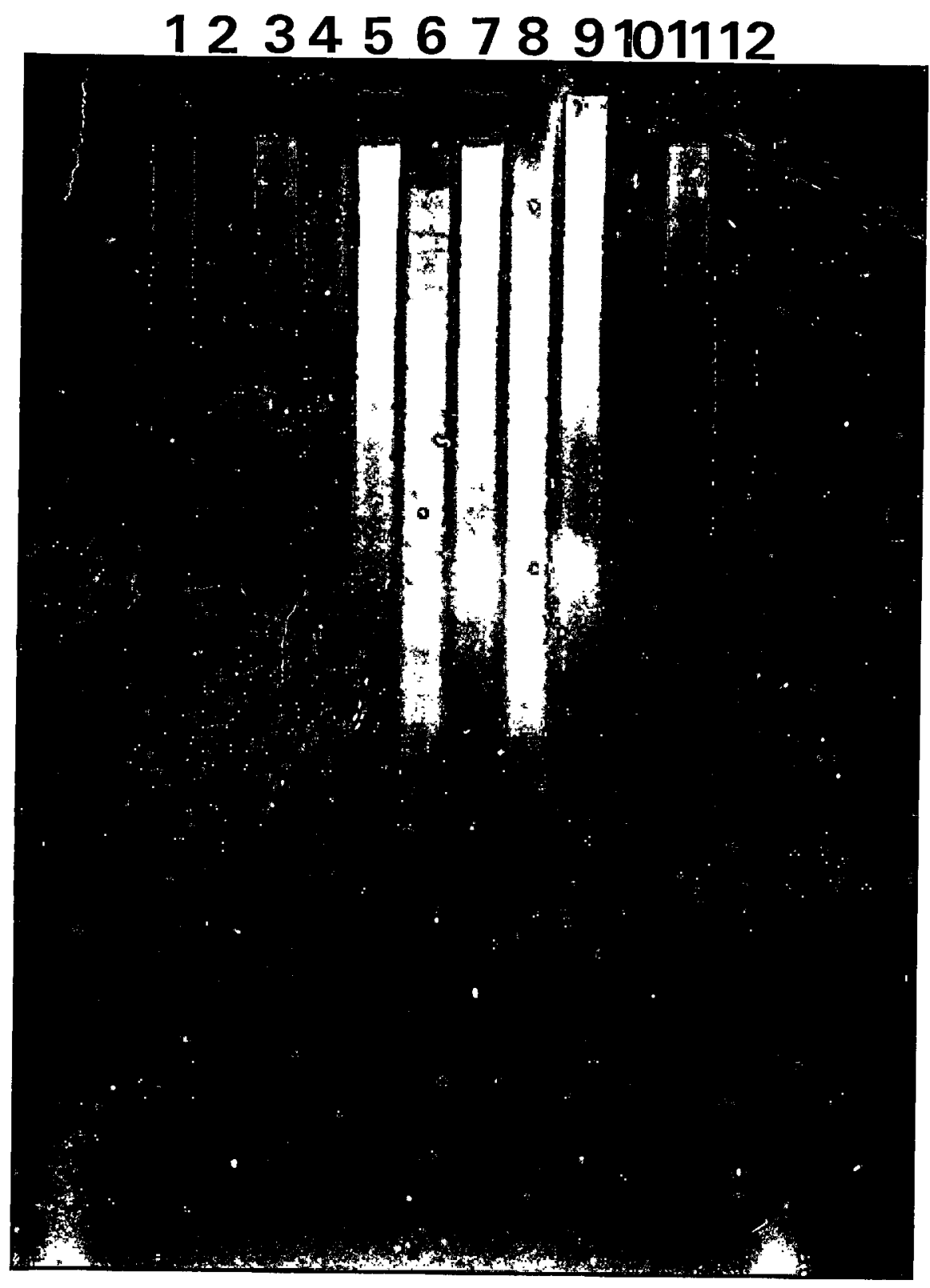

Figure 8. A 1\% agarose gel containing DNA from Synechococcus spp. cut with restriction enzymes EcoRI, HindIII and PstI. Lanes 1-3, SYNWH6501, lanes 4-6, Anabaena 7120, lanes 7-9, PCC7942 and lanes 10-12, PCC6301. 
synthesized. Hybridization of the E. coli fur gene to cyanobacterial DNA offers evidence that the two gene sequences are homologous and suggests then that a similar mechanism for iron uptake is operating within these organisms. In contrast, the absence of hybridization of the fur probe to DNA from marine Synechococcus using the same methodology indicates that possibly a different mechanism is regulating iron aquisition. This information on its own is not be significant, but combined with the absence of measurable siderophores from marine strains may indicate a fundamental difference in the iron uptake mechanisms.

\section{DISCUSSION}

Since iron supply and iron nutrition in these two systems is quite different, (Hutchins and others 1991) the presence of distinctly different mechanisms for optimizing cell growth in iron-limited environments is not surprising. The results do however, direct a focus on acquiring knowledge of what regulates the seemingly competitively advantageous strategies that enable Synechococcus spp. to achieve its numerical abundance. Such a regulatory mechanism, like siderophores for the freshwater species, will possibly be linked to the water column dynamics of iron input and availability in the marine system and would be of great significance in understanding the separate strategies for competition and success of cyanobacteria in these two natural environments. Probing DNA from Synechococcus 7002, a marine cyanobacteria that produces siderophores, with the E. coli fur gene is one approach that may offer more direct evidence for the occurrance of different uptake mechanisms. 
One complication of cyanobacterial molecular genetics is that the morphological and physiological diversity of the group creates the necessity of independent interpretation of data since findings for one species cannot necessarily be applied to another (Golden and others 1989). This preliminary data then, while providing evidence for different iron uptake mechanisms for freshwater and marine cyanobacteria, demands a more detailed analysis of gene expression in these organisms enlisting the use of reporter genes and regulatory sequences. The combination of these genetic approaches and the wealth of information on physiology and biochemical aspects of the cell provide a powerful tool for understanding the complex systems operating in these organisms. An example of this is the absence of siderophore production determined physiologically and the absence of homology to the fur probe determined with genetic techniques.

To date, the naturally transformable Synechococcus PCC7942 has been chosen as a model system for studies on photosynthesis and iron regulation due to its ease in genetic manipulation. Cloning in PCC7942 and other transformable cyanobacteria can be carried out using shuttle vectors which replicate in both $E$. coli and cyanobacterial cells or by direct incorporation of the DNA into the genome (Friedberg 1988). It is through these transformations and the use of reporter genes that we hope to further elucidate the iron uptake mechanisms in marine and freshwater Synechococcus spp. Although marine Synechococcus spp. have almost the same morphological characteristics as PCC7942, only Matsunaga et al. (1990) have successfully transformed a marine strain. While techniques are being developed to make marine Synechococcus amenable to genetic manipulation, 
more sophisticated techniques for the already amenable PCC7942 could potentially unfold significant findings on iron regulation in the cyanobacteria. Our lab is in the process of transforming PCC7942 with the shuttle plasmid pSG111 which contains Ampr , lac Z as a reporter gene and the E. coli "iron box" sequence to provide an iron controlled reporter plasmid. This strategy has been used by Calderwood (Calderwood and Mekalanos 1988) to confirm "Fe box" control in E. coli. Iron regulation of this gene could be determined by measuring the activity of the reporter gene transcriptional product, in this case B-galactosidase in transformed cells of 7942. Cells grown at low iron concentrations should have high levels of activity and the addition of iron should cause a decrease the measured activity. 


\section{CHAPTER V}

\section{SUMMARY AND CONCLUSIONS}

An optimal photosynthetic apparatus relys on the efficient transfer of light energy from $\mathrm{Chl}$ - $\underline{\mathrm{a}}$ and the phycobilin pigments which are important accessory pigments in cyanobacteria. Iron limitation results in decreased synthesis of these pigments impairing energy transfer for carbon and nitrogen metabolism which depend on reduced ferredoxin generated from photosynthesis. One aspect of the effect of low iron on nitrogen metabolism was explored further in marine strains of Synechococcus. Cells grown on low iron and high nitrate and incubated with added ammonium in the dark had high rates of dark carbon fixation. This response was not seen in cells grown with high nitrate and high iron concentrations. We propose that this increase reflects a shift to an alternate $\mathrm{CO}_{2}$ fixation pathway that enables the cell to bypass the more energetically expensive photosynthetic and nitrate reduction pathway and preferentially channel carbon to amino acids and other important cell components. We suggest that this finding could be important for developing an assay that would identify iron-limited populations in nitrate-rich waters.

The physiological and biochemical aspects of photosynthesis and primary productivity in cyanobacteria has been the focus of extensive research and as a result, much is known about these autotrophic organisms. Through the recent successes of genetic manipulation using $E$. coli techniques on 
cyanobacteria many of the processes controlling primary productivity can now be analyzed at the molecular level. For example, the recent cloning and sequencing of the nitrogen fixation (nif) gene has been useful in determining factors regulating expression of the nitrogenase genes in natural systems. The significance of homology of the $E$. coli fur gene to cyanobacterial DNA discussed in this work is the first step in determining a sequence in cyanobacteria that regulates the assimilation of iron which is central to an efficient photosynthetic apparatus and energy transfer.

The degree of iron stress linked to co-limitation by light or nitrogen availability quite possibly determines the mode by which cyanobacteria select competitive mechanisms for success in dilute open ocean systems. This work applies physiological and molecular biology techniques to underline the geochemical importance of cyanobacteria and their role in controlling primary productivity in the open ocean. Continuation of molecular techniques to construct reporter plasmids for looking at gene expression will be instrumental in identifying iron controlled genes in the cyanobacteria that can further elucidate how these organisms obtain and transfer iron. 


\section{REFERENCES}

Alberte, R.S., A. M. Wood, T. A. Kursar, and R. R. L. Guillard. "Novel phycoerythrins in Marine Synechococcus spp.: characterization and evolutionary and ecological implications." Plant Physiol. 75 (1984): 732 -739 .

Anderson, M. A. and F. M. M. Morel. "The influence of aqueous iron chemistry on the uptake of iron by the coastal diatom Thalassiosira weissflogii." Limnol. Oceanogr. 27 (1982): 789-813.

Boyer, G. L., A. H. Gillam, and C. Trick. "Iron Chelation and uptake." In The Cyanobacteria, ed. P. Fay and C. Van Baalen. 415-436. Amsterdam: Elsevier Science, 1987.

Calderwood, S.B. and J.J. Mekalanos. "Confirmation of the fur operator site by insertion of a synthetic oligonucliotide into an operon fusion plasmid." L. Bacteriol. 170 (1988): 1015-1017.

Carr, N.G. and M. Wyman. "Cyanobacteria: Their biology in relation to the oceanic picoplankton." In Photosynthetic Picoplankton, ed. $\mathrm{T}$. and $\mathrm{Li}$ Platt W.K.W. 159-204. 214. Ottawa: Canadian Bulletin of Fisheries and Aquatic Sciences, 1987.

Chereskin, Barbara M. and Paul A. Castelfranco. "Effects of Iron and Oxygen on Chlorophyll Biosynthesis." Plant Physiol 69 (1982): 112-116.

Duce, R. A. "The impact of atmospheric nitrogen, phosphorus, and iron species on marine biological productivity." In The Role of Air-Sea Exchange in Geochemical Cycling. ed. P. Buat-Menard. 497-529. Dordrecht, Holland: Reidel Publ. Co., 1986.

Flores, D. , J.L. Ramos, A Herrero, and M.G. Gurerrero. "Nitrate assimilation by cyanobacteria." In Photosynthetic Prokaryotes: Cell Differentiation and Function. ed. G.C. Papageorgiou and L. Packer. 363-87. Elsevier Science Publishing Co., Inc., 1983.

Friedberg, D. "Use of Reporter genes in cyanobacteria." Meth. Enzymol. 167 (1988): 736-747. 
Glover, H. E., B. B. Prezelin, L. Cambell, M. Wyman, and C. Garside. "A nitrate-dependent Synechococcus bloom in surface Sargasso Sea water." Nature 331 (1988): 161-163.

Golden, S.S., M.S. Nalty, and D.C. Cho. "Genetic relationship of two highly studied Synechococcus strains designated Anacystis nidulans." I. Bacteriol. 171 (1989): 24-29.

Golden, S.S. and L.A. Sherman. "Optimal conditions for genetic transformation of the cyanobacterium Anacystis nidulans R2." I. Bacteriol. 158 (1984): 36-42.

Guikema, J. A. and L. A. Sherman. "Influence of iron deprivation on the membrane composition of Anacystis nidulans." Plant Physiol. 74 (1984): 90-95.

Hardie, L.P., D.L. Balkwill, and Jr. S.E. Stevens. "Effects of iron starvation on the physiology of the cyanobacterium Agmenellum quadruplicatum." Applied and Env. Microbiol. 45 (1983): 999-1006.

Hodge, V. , S.R. Johnson, and E.D. Goldberg. "Influence of atmospherically transported aerosols on surface water composition." Geochem. I. 12 (1978): 7-20.

Hutchins, D. A., J. G. Rueter, and W. Fish. "Siderophore production and nitrogen fixation are mutually exclusive strategies in Anabaena 7120." Limnol. Oceanogr. 36 (1991): 1-12.

Jones, K. L. "Analysis of ferredoxin and flavodoxin in Anabaena and Trichodesmium using fast protein liquid chromatography." Master of Science, Portland State University, Portland, Oregon,, 1988.

Keller, M.D., W.K. Bellows, and R.R.L Guillard. "Microwave treatment for sterilization of phytoplankton culture media." I. exp. Mar. Biol. Ecol. 117 (1988): 279-283.

Laudenbach, D.E., M.E. Reith, and N.A. Straus. "Isolation, sequence analysis, and transcriptional studies of the flavodoxin gene from Anacystis nidulans R2." I. Bacteriol. 170 (1988): 258-265.

Maniatis, T., E.F. Fritsch, and J. Sambrook. Molecular Cloning, a laboratory Manual. Cold Spring Harbor Laboratory, 1982. 
Martin, J.H. "Glacial-interglacial CO2 change: the iron hypothesis." 5 (1990): 113.

Martin, J. H. and S.E. Fitzwater. "Iron deficiency limits phytoplankton growth in the north-east Pacific subarctic." Nature 331 (1988a): 341-343.

Martin, J. H. and S.E. Fitzwater. "Iron deficiency limits phytoplankton growth in the north-east Pacific subarctic." Nature 331 (1988b): 341-343.

Martin, J. H. and R.M. Gordon. "Northeast Pacific iron distributions in relation to phytoplankton productivity." Deep-Sea Res. 35 (1988): 177196.

Matsunaga, T., H. Takeyama, and N. Nakamura. "Characterization of cryptic plasmids from marine cyanobacteria and construction of a hybrid plasmid potentially capable of transformation of marine cyanobacterium, Synechococcus sp., and its transformation." 24/25 (1990): 151-160.

Mazur, B. J., D. Rice, and R. Haselkorn. "Identification of blue-green algal nitrogen fixation genes by using heterologous DNA hybridization probes." Proc. Natl. Acad. Science (USA) 77 (1980): 186-190.

Moore, R. M., J. E. Milley, and A. Chatt. "The potential for biological mobilization of trace elements from aeolian dust in the ocean and its importance in the case of iron." Oceanologica Acta 7 (1984): 221-8.

Morel, F.M.M., J.G. Rueter, and D.M. Anderson. "Aquil: A chemically defined phytoplankton culture medium for trace metal studies." I. Phycol. 15 (1979): 135-141.

Parsons, T.R., Y. Maita, and C.M. Lalli. "A manual of chemical and biological methods for seawater analysis." Pergamon Press, 1984.

Peschek, G.A. "Nitrate and nitrite reductase and hydrogenase in Anacystis nidulans grown in Fe- and Mo-deficient media." FEMS Microbiol. Lett. 6 (1979): 371-374.

Pick, F. R. and D. R. S. Lean. "The role of macronutrients (C, N, P) in controlling cyanobacterial dominance in termperate lakes." $\mathrm{N}$. Z. I. Mar. \& Freshwater. Res. 21 (1987a): 425-434. 
Pick, F. R.] and D. R. S. Lean. "The role of macronutrients (C, N, P) in controlling cyanobacterial dominance in termperate lakes." $\mathrm{N}$. Z. I. Mar. \& Freshwater. Res. 21 (1987b): 425-434.

Platt, T. and W. G. Harrison. "Biogenic fluxes of carbon and oxygen in the ocean." 318 (1985): 55-58.

Platt, T. and S. Sathyendranath. "Oceanic primary production: Estimation by remote sensing at local and regional scales." 241 (1988): 1613-1619.

Reddy, K.J., G.S. Bullerjahn, D.M. Sherman, and L.A. Sherman. "Cloning, nucleotide sequence, and mutagenesis of a gene (irpA) involved in iron-deficient growth of the cyanobacterium Synechococcus sp. strain PCC7942." L. Bacteriol. 170 (1988): 4466-4476.

Rueter, J. G. and D. R. Ades. "The role of iron nutrition in photosynthesis and nitrogen assimilation in Scenedesmus quadricauda (Chlorophyceae)." I. Phycol. 23 (1987): 452-7.

Rueter, J. G. and N. L. Unsworth. "Response of marine Synechococcus (Cyanophyceae) cultures to iron nutrition." L. Phycol. 27 (1991): in press.

Rueter, J. G., N. L. Unsworth, R. W. Collier, and C. Meredith. "Uptake of iron by the marine cyanobacterium, Synechococcus ." Biol. Ocean. Manuscript in prep. (man.):

Sandmann, G. and R. Malkin. "Iron-sulfur centers and activities of the photosynthetic electron transport chain in iron-deficient cultures of the blue-green alga Aphanocapsa." Plant Physiol. 73 (1983): 724-728.

Scanlan, D.J., N.H. Mann, and N.G. Carr. "Effect of iron and other nutrient limitations on the pattern of outer membrane proteins in the cyanobacterium Synechococcus PCC7942." Arch. Microbiol. 152 (1989): 224-228.

Schaffer, S., K. Hantke, and V. Braun. "Nucleotide sequence of the regulator gene fur." Mol Gen. Genet. 200 (1985): 110-113.

Schneegurt, M.A. and S.I. Beale. "Characterization of the RNA required for biosynthesis of $\partial$-aminolevulinic acid from glutamate." Plant Physiol. 86 (1988): 497-504. 
Siegelman, H.W. and J.H. Kycia. "Algal biliproteins." In Handbook of Phycological Methods: Physiological and Biochemical Methods., ed. J.A. Hellebust and J.S. Craigie. 71-79. Cambridge: Cambridge University Press., 1978.

Simpson, F.B. and J.G. Neilands. "Siderochromes in cyanophyceae: isolation and characterization of schizokinen from Anabaena sp." L. Phycol. 12 (1976): 44-48.

Spiller, Susan C., Ann M. Castelfranco, and Paul A. Castelfranco. "Effects of Iron and Oxygen on Chlorophyll Biosynthesis." Plant Physiol 69 (1982): 107-111.

Syrett, P.J. "Nitrogen metabolism in microalgae." In Physiological bases of phytoplankton ecology, ed. T. Platt. 182-210. Hull, Quebec: Government Publishing Centre, 1981.

Tabita, F. Robert. "Molecular and Cellular Regulation of Autotrophic Carbon Dioxide Fixation In Microorganisms." 52 number No.2 (1988): 155-189.

Theil, T., J. Bramble, and S. Rogers. "Optimum conditions for growth of cyanobacteria on solid media." FEMS Microbiol. Lett. 61 (1989): 27-32.

Turpin, D.H. "Effects of inorganic $N$ availability on algal photosynthesis and carbon metabolism." I. Phycol. 27 (1991): 14-20.

Vincent, W. F. "Rapid physiological assays for nutrient demand by the plankton. I. Nitrogen." I. Plankton Res. 3 (1981): 685-697.

Waterbury, J. B., S. W. Watson, R. R. L. Guillard, and L. E. Brand. "Widespread occurrence of a unicellular, marine, planktonic, cyanobacterium." Nature 277 (1979): 293-294.

Wheeler, P. A. and S. A. Kokkinakis. "Ammonium recycling limits nitrate use in the oceanic subarctic Pacific." Limnol. Oceanogr. 35 (1990): 12671278.

Wood, A. M. and D. Townsend. "DNA polymorphism within the WH7803 serogroup of marine Synechococcus spp. (Cyanobacteria)." L. Phycol. 26 (1990): 576-585.

Zhuang, G., R.A. Duce, D.R. Kester. "The Dissolution of Atmospheric Iron in Surface Seawater of the Open Ocean." I. Geophys. Research. 95 (1990): $16,207-16,216$. 
APPENDIX A

ALGAL CULTURE TECHNIQUES 
Cultures of Synechococcus WH7803, WH6501 and WH8018 were obtained from the Center for the Culture of Marine Phytoplankton, Bigelow Laboratory for Ocean Sciences. Agar slants of Anacystis nidulans R2 (PCC7942) were kindly provided from the laboratories of Dr. Susan Golden and Dr. David Laudenbach. Synechococcus 6301 was obtained from Dr. John Goldbeck, Dept. of Chemistry, PSU. Anabaena 7120 was obtained from Dr. William Fish, Oregon Graduate Institute.

Marine strains of Synechococcus spp. were grown in AQUIL medium (Morel and others 1979) used previously in iron nutritional studies in our laboratory because it has characterized speciation and low background iron levels ( $2 \times 10^{-9} \mathrm{M}$ or less). The synthetic ocean water (SOW), nutrients $\left(\mathrm{NO}_{3}\right.$ and $\mathrm{PO}_{4}$ ) and vitamins were made up in 1 liter batches and passed through a column containing Chelex-100 ion exchange resin (Bio Rad) to remove any contaminating trace metals. The trace metals (containing $5 \times 10^{-6} \mathrm{M}$ EDTA with no iron) were then added and the medium was filter sterilized by passage through a $0.2 \mu \mathrm{m}$ pore size Nuclepore filter in an acid washed polycarbonate (Millipore) filter apparatus. The medium then underwent a final microwave sterilization procedure to reduce the risk of algal or bacterial contamination (Keller and others 1988) Cultures were grown in 1 or $2 \mathrm{~L}$ polycarbonate bottles at $25^{\circ} \mathrm{C}$ with cool white fluorescent bulbs providing continuous illumination at 50-70 $\mu \mathrm{mol}$ photons $\mathrm{m}^{-2} \mathrm{~s}^{-1}$. These irradiance levels were chosen based on reports that these clones (WH7803 and WH8018, for example) saturate in the region of $75 \mu \mathrm{mol}$ photons $\mathrm{m}^{-2} \mathrm{~s}^{-1}$ and are very sensitive to photoinhibition (Alberte and others 1984). All culture work was carried out in a plastic enclosure containing a 
HEPA-filtered laminar flow hood drawing air from outside the enclosure to create positive pressure in an effort to keep dust out. This "tent" is necessary to prevent iron-bearing dust from contaminating the cultures. The chelex-filtration apparatus set up was placed in the tent directly under the laminar flow hood. Prior to experimentation, cultures were grown through at least three transfers to insure that cells were acclimated to iron and nutrient conditions.

Cultures of Anabaena 7120 and Synechococcus 6301 were grown in Kratz and Myers medium that was made up in liter batches, autoclaved for 20 minutes, cooled to room temperature and bubbled with $\mathrm{CO}_{2}$ until cleared of precipitates. The required volume of medium was transferred to sterilized glass ehrlenmeyer flasks prior to inoculation from a stock culture. Anacystis nidulans R2 was maintained in BG-11 medium (Thiel and others 1989) that underwent the same sterilization procedure described for Kratz and Myers medium. Cultures of each strain were grown at $25^{\circ} \mathrm{C}$ with cool white fluorescent bulbs providing continuous illumination at $100 \mu \mathrm{mol}$ photons $\mathrm{m}^{-}$ $2 \mathrm{~s}^{-1}$. Culture vessels for both the marine and fresh water cyanobacteria were agitated daily by hand to provide sufficient gas exchange and to resuspend cells. All plasticware and glassware used for trace metal work was soaked in $4 \%$ acid for a minimum of 4 hours and then rinsed five times in nanopure water and dried under a hood or enclosed area. 
BG - 11 GROWTH MEDIA FOR PCC 7942

\begin{tabular}{|c|c|c|c|}
\hline Solution Components & $\begin{array}{l}\text { olution } \\
\text { tration } \mathrm{mg} / \mathrm{l}\end{array}$ & $\begin{array}{c}\begin{array}{c}\text { Final } \\
\text { Molarity } \\
\text { of Solution }\end{array} \\
\end{array}$ & $\begin{array}{c}\text { Stock } \\
\text { Solution }\end{array}$ \\
\hline Solution 1 -- $\mathrm{NaNO}_{3}$ & 1500.0 & $1.8 \times 10^{-4}$ & $100 x$ \\
\hline Solution $2-\mathrm{MgSO}_{4} \cdot 7 \mathrm{H}_{2} \mathrm{O}$ & 100.0 & $4.0 \times 10^{-8}$ & $1000 x$ \\
\hline Solution $3--\mathrm{CaCl}_{2} \cdot 2 \mathrm{H}_{2} \mathrm{O}$ & 3.06 & $2.4 \times 10^{-8}$ & $1000 x$ \\
\hline Solution $4--\mathrm{K}_{2} \mathrm{HPO}_{4} \cdot 3 \mathrm{H}_{2} \mathrm{O}$ & 40.0 & $2.3 \times 10^{-8}$ & $1000 x$ \\
\hline Solution $5--\mathrm{Na}_{2} \mathrm{CO}_{3}$ & 20.0 & $1.9 \times 10^{-8}$ & $1000 x$ \\
\hline Solution 6 -- citric acid & 6.6 & $3.1 \times 10^{-7}$ & \\
\hline ferric ammonium citrate & 6.0 & $2.0 \times 10^{-7}$ & \\
\hline $\mathrm{Na}_{2} \mathrm{Mg}$ EDTA & 1.0 & $2.8 \times 10^{-6}$ & $1000 x$ \\
\hline Solution $7--\mathrm{H}_{3} \mathrm{BO}_{3}$ & 2.86 & $4.6 \times 10^{-7}$ & \\
\hline $\mathrm{MnCl}_{2} \bullet 4 \mathrm{H}_{2} \mathrm{O}$ & 1.81 & $9.1 \times 10^{-6}$ & \\
\hline $\mathrm{ZnSO}_{4} \cdot 7 \mathrm{H}_{2} \mathrm{O}$ & 0.22 & $7.7 \times 10^{-6}$ & \\
\hline $\mathrm{Na}_{2} \mathrm{MoO}_{4} \cdot 2 \mathrm{H}_{2} \mathrm{O}$ & 0.39 & $1.6 \times 10^{-6}$ & \\
\hline $\mathrm{CuSO}_{4} \cdot 5 \mathrm{H}_{2} \mathrm{O}$ & 0.08 & $3.2 \times 10^{-5}$ & \\
\hline $\mathrm{Co}\left(\mathrm{NO}_{3}\right)_{2} \bullet 6 \mathrm{H}_{2} \mathrm{O}$ & 0.05 & $1.7 \times 10^{-5}$ & $1000 x$ \\
\hline
\end{tabular}


GROWTH MEDIA FOR SYN 6301 AND ANABAENA 7120

Stock Name Component Conc. (g/l) Final Molarity of Component

TRACE COMPONENT

\begin{tabular}{|c|c|c|}
\hline $\mathrm{FeSO}_{4} \cdot 7 \mathrm{H}_{2} \mathrm{O}$ & 6.0 & $3.60 \times 10^{-5}$ \\
\hline NTA or EDTA & 10.0 & $7.09 \times 10^{-5}$ \\
\hline $\mathrm{MnSO}_{4} \cdot \mathrm{H}_{2} \mathrm{O}$ & 0.86 & $1.04 \times 10^{-5}$ \\
\hline $\mathrm{ZnSO}_{4} \cdot 7 \mathrm{H}_{2} \mathrm{O}$ & 0.52 & $3.01 \times 10^{-6}$ \\
\hline$\left(\mathrm{NH}_{4}\right)_{6} \mathrm{Mo}_{7} \mathrm{O}_{24} \bullet 4 \mathrm{H}_{2} \mathrm{O}$ & 0.44 & $5.93 \times 10-7$ \\
\hline $\mathrm{CoCl}_{2} \cdot 6 \mathrm{H}_{2} \mathrm{O}$ & 0.24 & $1.68 \times 10^{-6}$ \\
\hline $\mathrm{NH}_{4} \mathrm{VO}_{3}$ & 0.028 & $3.99 \times 10^{-7}$ \\
\hline $\mathrm{CuSO}_{4} \cdot 5 \mathrm{H}_{2} \mathrm{O}$ & 0.24 & $1.60 \times 10^{-6}$ \\
\hline
\end{tabular}

MACRO COMPONENT

$\begin{array}{lcc}\mathrm{MgSO}_{4} \bullet 7 \mathrm{H}_{2} \mathrm{O} & 30.0 & 1.01 \times 10^{-3} \\ \mathrm{KNO}_{3} & 133.6 & 1.00 \times 10^{-2} \\ \mathrm{Ca}\left(\mathrm{NO}_{3}\right)_{2} \bullet 4 \mathrm{H}_{2} \mathrm{O} & 3.89 & 1.06 \times 10^{-4} \\ \mathrm{NaCl} & 14.0 & 2.00 \times 10^{-3}\end{array}$

PHOSPHATE COMPONENT

$\mathrm{K}_{2} \mathrm{HPO}_{4}$

$1.01 \times 10^{-3}$

BICARBONATE COMPONENT

$\mathrm{KHCO}_{3}$

$2.52 \times 10^{-3}$ 
APPENDIX B

BIOCHEMICAL AND PHYSIOLOGICAL TECHNIQUES 
$\mathrm{Chl}$ a content for all samples was determined by a common fluorometric method using 90\% acetone extractions (Parsons and others 1984). $10 \mathrm{~mL}$ replicate samples of each culture were filtered onto Whatman GF/F glass fiber filters through a Gelman polycarbonate funnel attached to a suction filtration apparatus set up. Two drops of saturated $\mathrm{MgCO}_{3}$ was added to each filter to prevent loss of the magnesium ion. Filters were then stored in the freezer in a dark box until later analysis. Analysis of the frozen filters involved grinding in $10 \mathrm{~mL}$ of $90 \%$ acetone (v/v) using a tissue homogenizer. The sample was allowed to extract overnight in a dark box at $4^{\circ} \mathrm{C}$ and was then analyzed fluorometrically on a Turner Designs Model 10 fluorometer calibrated for chlorophyll a . Micrograms Chl-a were determined using the equation (Fluorescence)x(.03862). This value is multiplied by the volume of acetone $(10 \mathrm{~mL})$ and divided by the volume of culture filtered $(10 \mathrm{~mL})$ to give $\mu \mathrm{g} \mathrm{Chl}-\underline{\mathrm{a}} / \mathrm{mL}$ of culture.

Two different methods for estimating phycoerythrin from marine Synechococcus spp. were used. In experiments measuring only the increase in phycoerythrin with added iron, the glycerol method of Carr and Wyman was used. $1.5 \mathrm{~mL}$ of each culture to be analyzed was pipetted into a plastic cuvette and $1.5 \mathrm{~mL}$ of glycerol was also pipetted into the cuvette using a Jetpipettor. The top of the cuvette was sealed with Parafilm and shaken vigorously to mix the culture medium and glycerol. After all the air bubbles had disappeared the fluorescence was measured on a Jasco FP 550 spectrofluorometer set at $510 \mathrm{~nm}$ excitation and $562 \mathrm{~nm}$ emission. The observed increases in phycoerythrin are a result of the uncoupling of the 
protein from energy transduction. The fluorescence in vivo of cultures with no glycerol added was also measured as a baseline value for comparison.

Phycoerythrin(PE), phycocyanin (PC) and allphycocyanin (APC)

concentrations were measured spectrophotometrically after extraction using a modification of the method described by Stewart and Farmer (1984). Cultures were filtered onto Gelman filter type $\mathrm{AE}$ or Whatman GF/F and frozen until analysis. Filters were thoroughly homogenized in a solution consisting of $0.25 \mathrm{M}$ Trizma Base (Sigma), 10mM disodium EDTA, and $2 \mathrm{mg} \mathrm{mL}^{-1}$ lysozyme at $\mathrm{pH} 5$ using a tissue homogenizer. Samples were incubated in foil wrapped tubes at $37^{\circ} \mathrm{C}$ for $2 \mathrm{~h}$ and then $24 \mathrm{~h}$ at $4{ }^{\circ} \mathrm{C}$. Following the $24 \mathrm{~h}$ incubation, the $\mathrm{pH}$ was adjusted to 7.0 and the total volume $(6 \mathrm{~mL})$ was increased to twice the original with distilled water. The sample was filtered to produce a clear homogenate. Phycobilin concentrations were calculated using an equation correcting for spectral overlaps of the pigments (Siegelman and Kycia 1978). This method was used when a $\mu \mathrm{g} / \mu \mathrm{l}$ phycoerythrin content as a percent of total phycobilins was measured; however, it is very time consuming and the glycerol method is much more convenient for determining relative increases or decreases in pigment concentrations.

\section{MEASUREMENT OF TOTAL CELLULAR PROTEIN}

All protein concentrations were measured using the BCA Protein Assay (Pierce). This assay can be used in the presence of detergents without interference. For all the samples in this study $1 \% \mathrm{w} / \mathrm{v}$ SDS (sodium dodecyl sulphate) was used to completely solubilize all cell protein including membrane-bound hydrophobic components. Based on culture density and 
volume of filtered sample, either the "Enhanced" or "Room Temperature" protocol described in the Pierce Protein Assay instruction manual was used. $50 \mathrm{~mL}$ of culture was filtered through Whatman GF/F glass fiber filters. In many cases when cultures were being sampled daily for several physiological parameters, less culture was used to conserve the volume. However, depending on the density of the culture, less than $25 \mathrm{~mL}$ for the marine Synechococcusspp. did not usually produce a measurable amount of protein. After filtration the filters were frozen and then ground with a teflon tissue homogenizer in $3 \mathrm{~mL}$ of $1 \%$ SDS. Because this is a lot of filter for such a small volume of liquid, initially grinding the filter in $1 \mathrm{~mL}$ of SDS and then two steps of rinsing and grinding with the remaining $2 \mathrm{~mL}$ was done to get all of the material. The supernatant from the homogenized filters was incubated at $4{ }^{\circ} \mathrm{C}$ overnight to insure complete solubilization of the proteins. The next day, the tubes were spun for 5 minutes at high speed on a desk top centrifuge to obtain a filter-free, clear supernatant. To $100 \mu \mathrm{L}$ of supernatant, $2 \mathrm{~mL}$ of BCA Working Reagent was added. The working reagent contains detection reagent mixed with $4 \% \mathrm{CuSO}_{4}$ in a $50: 1 \mathrm{v} / \mathrm{v}$ ratio. For most of the protein samples in this study the Enhanced protocol was used for measurement of concentrations ranging from $10-250 \mu \mathrm{g} / \mathrm{mL}$. In a few cases with more dense cultures, the Room Temperature protocol was used for measuring protein concentrations between $100-1200 \mu \mathrm{g} / \mathrm{mL}$. Absorbance of the samples was measured at $562 \mathrm{~nm}$ in a $1 \mathrm{~cm}$ cell and the protein concentration determined graphically using a standard curve generated with BSA (bovine serum albumen) provided with the assay kit. A separate curve was generated for the different protocols. 


\section{MEASUREMENT OF CARBON FIXATION RATES}

Carbon fixation rate was estimated by the uptake of a ${ }^{14} \mathrm{C}$ stock that had been passed through a Chelex-100 column (BioRad) to remove contaminating trace metals. Prior to assaying for carbon fixation rate cultures were sampled for $\mathrm{Chl}-\underline{a}$, nitrate, and protein concentration, and cell density. Cultures were then spiked with $1 \mu \mathrm{Ci} / \mathrm{mL} \mathrm{NaH}^{14} \mathrm{CO}_{3}$ and replicate $15 \mathrm{~mL}$ aliquots were incubated for three hours at $70 \mu \mathrm{mol}$ photons $\mathrm{m}^{-2} \mathrm{~s}^{-1}$ and in foil wrapped tubes for dark incubation. Carbon fixation rates for the ammonium enhancement experiments were measured as above, but a separate set of replicate tubes incubated at both light and dark conditions were spiked with $5 \mu \mathrm{M}$ ammonium chloride in addition to $\mathrm{NaH}^{14} \mathrm{CO}_{3}$. Following the threehour incubation all tubes were removed from the light field and each sample was collected onto a GF/F filter using a vacuum filtration apparatus. Filters were placed in $7 \mathrm{~mL}$ disposable polypropylene scintillation vials and allowed to dry overnight. Once filters were dry $3 \mathrm{~mL}$ of Solvent Free liquid scintillation cocktail (Isolab, Inc.) were added to the vials and samples were counted in a Beckman Liquid Scintillation Counter.

\section{CELL COUNTS}

There is a great deal of difficulty encountered in obtaining accurate cell counts for Synechococcus and cell density is a very important parameter for the experiments in this study. Three different methods were used throughout the work presented in this thesis; however, only one method was used consistently during each individual experiment. 1) Coulter Counter: 
cell density was measured using a Coulter Counter (Model 2907 ZBI) fitted with a $30 \mu \mathrm{M}$ aperature. Difficulty was encountered in obtaining reliable cell counts due to clogging of the aperture opening by clumped Synechococcus cells. This was especially noticeable when counting iron-limited cells which exhibited a great deal of clumping when viewed under the microscope. Under these circumstances, samples were diluted to prevent clogging. To insure the greatest accuracy possible, four to six counts were taken for each sample and averaged. 2) Microscopic counts using a hemocytometer: $50 \mu \mathrm{l}$ of culture was pipetted into a Fuchs Rosenthal ultrapure hemocytomer (1/16sq. $\mathrm{mm}$ and $2 / 10 \mathrm{~mm}$ deep) and visually counted on a microscope equipped with a $100 \mathrm{X}$ objective. Cultures counted in this way usually required dilution prior to counting. Clumping of cells was also a problem with this method because it was difficult to distinguish individual cells. 3) Fluorescence microscopy: Samples were filtered onto $.4 \mu \mathrm{M}$ Nuclepore filters $(25 \mathrm{~mm})$ using a Millipore glass chimney. To achieve even distribution of the sample on the filter, a Whatman GF/F was placed between the membrane filter and the filter base. Prior to placement of the membrane filter, the GF/F filter was placed on the salt solution and vacuum filtered evenly onto the backing filter. After filtration of the sample under low vacuum, the membrane filter was removed and put (sample side up) on top of a drop of immersion oil on a microscope slide. Another drop of oil was placed on top and a coverslip gently pressed on top. The slide was then inverted onto a paper towel and the excess oil blotted away and the cover slip gently flattened. Cells were then counted on a standard Zeiss scope with a neofluar objective and an epifluorescent system equipped with a filter set in which phycoerythrin 
fluoresced orange. The number of cells $\mathrm{mL}^{-1}$ was calculated using the following equation: Cells field ${ }^{-1}$ divided by $\mathrm{mL}$ sample filtered $\times\left(2 \times 10^{4}\right)$

(Waterbury and others 1979). This method was the most effective for producing accurate cell counts, but it requires quite a bit of experimenting with dilution of the culture to obtain a filtrate that is not too dense to count. More than 50 cells per field is difficult to count accurately. 
APPENDIX C

MOLECULAR BIOLOGY TECHNIQUES 
Chromosomal DNA from Anacystis nidulans R2 PCC7942, Synechococcus WH6501, WH6301 and Anabaena 7120 was isolated from cultures for use in Southern blot hybridizations with a radiolabled probe to look for the presence of homologous sequences to the bacterial fur gene, which plays an important role in iron regulation in E. coli (Schaffer and others 1985). For the freshwater strains DNA was prepared using a slightly modified method of Mazur et al. (1980) For DNA isolation from the marine Synechococcus WH6501 a modified version of Wood and Townsend (1990) was followed.

For PCC7942, PCC6301 and Anabaena 7120, 250-500mL of culture (500 $\mathrm{ml}$ yielded approximately $5 \mu \mathrm{g}$ of DNA) was centrifuged at $10,000 \mathrm{rpm}$ for 10 minutes in $250 \mathrm{~mL}$ bottles using a Sorval RC-2 centrifuge. The supernatant was removed and the remaining pellet washed once with fresh media and centrifuged again as above. The supernatant was carefully drawn off with a pipet leaving the pellet as dry as possible. The pellet underwent three freeze/thaw periods followed by suspension of the thawed pellet in $5 \mathrm{~mL}$ of TE buffer (Maniatis and others 1982). The suspension was transferred to a $15 \mathrm{~mL}$ polyethylene centrifuge tube lysozyme was added to a final concentration of $2 \mathrm{mg} / \mathrm{mL}$ and the tube was incubated for 2 hours at $37^{\circ} \mathrm{C}$. $25 \mu \mathrm{L}$ of Triton $100,25 \mu \mathrm{L}$ of proteinase $\mathrm{K}$ and SDS (to a final concentration of $.5 \%$ ) was then added and the tube incubated overnight at $50^{\circ} \mathrm{C}$. The next day, an equal volume of TE equilibrated phenol was added and mixed for 3.5 minutes by gently inverting the tube. The sample was then spun at maximum speed on a desk-top centrifuge for 5 minutes. To the aqueous layer, one volume of ice-cold $100 \% \mathrm{EtOH}$ was added. The tube was inverted 
until a white, stringy precipitate formed and this was spooled with the tip of a pasteur pipet that had been sealed with a bunsen burner flame. The DNA was dissolved in $2 \mathrm{~mL}$ of TE buffer (this can take several hours). The DNA was then reprecipitated with 1.5 volumes of isopropanol and once again spooled and rinsed with $70 \% \mathrm{EtOH}$. The excess $\mathrm{EtOH}$ was drained and the DNA resuspended in $100 \mu \mathrm{L}$ of TE in a $1.5 \mathrm{~mL}$ Eppendorf centrifuge tube and stored at $-20^{\circ} \mathrm{C}$ until ready for use.

Extreme caution should be exercised when handling phenol. Gloves and goggles should be worn during these steps and make certain that the caps are tightened before inverting the tubes to mix. When removing the aqueous layer from the phenol, avoid the white layer at the interface. This contains proteins that will lower the purity of the DNA.

\section{ANALYSIS BY ENZYME DIGESTION AND SOUTHERN BLOTTING}

Approximately $1 \mu \mathrm{g}$ of DNA from each sample was digested for a

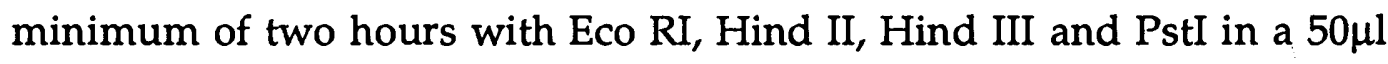
volume at $37^{\circ} \mathrm{C}$. After several hours a $1 / 10$ volume of loading buffer (Maniatis and others 1982) was added to the restriction mix and spun in a microfuge for 30 seconds. The entire sample volume was loaded into a $1 \%$ agarose gel containing ethidium bromide. $10 \mu \mathrm{l}$ of a molecular weight standard containing a range of expected size fragments was loaded into the wells at each side of the samples on the gel. The gel was covered with $1 \mathrm{~mm}$ of TBE buffer and hooked up to a power supply. The gel should be run at $100 \mathrm{~V}$ for about 10 minutes or until the purple and blue dye bands can be seen separately in the gel and then reduced to $20 \mathrm{~V}$ and run for about 16 hours. 
After electrophoresis the gel was placed in a glass pyrex dish and the DNA was depurinated by gentle agitation in a $.25 \mathrm{~N} \mathrm{HCl}$ solution for $10-15$ minutes (It is important not to exceed 15 minutes and 10 minutes is best). It is important for the gel to be free floating during all periods of agitation. The $\mathrm{HCl}$ was then poured off and the DNA denatured by soaking the gel in $.5 \mathrm{~N}$ $\mathrm{NaOH}, 1 \mathrm{M} \mathrm{NaCl}$ for 30 minutes with gentle agitation. After 30 minutes that buffer was removed and the gel was neutralized by bathing for 30 minutes in $.5 \mathrm{M}$ Tris- $\mathrm{HCl} \mathrm{pH} 7.4$ and $3 \mathrm{M} \mathrm{NaCl}$. During the last soaking period, 5 sheets of Whatman 3MM paper were cut to the exact size of the gel and one sheet of Zetaprobe blotting membrane (BioRad) was cut slightly smaller than the gel. The cut sheet of Zetaprobe was soaked in distilled water for 5 minutes prior to use. Two sponges were pressed firmly together and placed in the pyrex dish. 10X SSC is then poured over the sponges until the buffer is half way up the side of the sponge. The gel was photographed on a UV transilluminator and gently placed on top of the sponge and three pieces of wetted 3MM paper. A gloved hand was used to press away any bubbles from between the gel and the $3 \mathrm{MM}$ paper. The gel was then flooded with 10X buffer and the presoaked Zetaprobe carefully placed over the top of the gel so that it is in perfect alignment. It is important to keep smoothing the gel and membrane so that there are no air bubbles. The gel and pyrex dish are then sealed with Saran Wrap and, with a razor, the wrap around the gel is cut out creating a "window" so that only the membrane is exposed. This insures that capillary action will only go through the gel. The remaining two sheets of buffer soaked 3MM paper are placed on top of the gel and smoothed. A 6-10 inch stack of paper towels cut to the size of the gel are placed over the gel sandwich 
and the entire stack is covered with a piece of plexiglass and a $100 \mathrm{ml}$ beaker filled with water to use as a weight. The gels were blotted from 12 to 24 hours after which the paper towels and 3MM paper was removed and the membrane was rinsed briefly in 2 XSC. The membrane filter was air-dried between two pieces of filter paper and, since hybridization was not carried out immediately, the membrane was baked at $80^{\circ} \mathrm{C}$ for 30 minutes. It can then be stored between two pieces of filter paper in plastic bags or plastic wrap at room temperature.

It is important to use caution when doing all these procedures. Ethidium bromide is a powerful mutagen and gloves should be worn at all times. Gloves without powder are preferable since the powder often gets on the gel and produces black spots all over the developed film.

\section{PREPARATION AND RADIOLABELLING OF THE FUR PROBE}

An agar stab of bacteria bearing plasmid pMH15, which carries a $2.2 \mathrm{~kb}$ insert in the pACY184 vector and contains the E. coli fur gene, was generously provided by Klaus Hantke. Two $5 \mathrm{~mL}$ overnight cultures were grown up with chloramphenicol and mini plasmid preps were carried out using Qiagen columns (Qiagen) to insure that there was no RNA contamination. The plasmid DNA underwent a double digestion with AccI and Bgll to isolate the $1.1 \mathrm{~kb}$ fragment containing the fur gene. Isolation of the fragment was accomplished by gel electrophoresis of the restriction mix on a $1 \%$ low melting temperature agarose (SeaKem) gel. The DNA was run with Lamda/HindIII and pBR322/phiX markers to identify the correct band size. Bands fluoresce when the gel containing ethidium bromide is placed on a UV 
transilluminator and the bandscan be cut out of the gel using a razor blade. The DNA was further purified using a Prep-a-Gene kit (BioRad). The DNA was radiolabeled with $5 \mu 1$ of $32 \mathrm{P}$ labeled $\mathrm{dCTP}$ using a random priming kit (Boehringer Mannheim).

The membrane containing the DNA was placed in a Seal-a-Meal bag and $15 \mathrm{~mL}$ of prehybridization solution with $250 \mu \mathrm{g} / \mathrm{ml}$ of denatured salmon sperm DNA (to block non-specific binding) was added to the bag. The air bubbles were squeezed from the bag and it was then sealed and placed in a water bath at $37^{\circ} \mathrm{C}$ for 2 hours to overnight. The membrane filters underwent prehybridization overnight along with labelling and incorporation of the probe. After at least 4 hours of prehybridization, the probe was added to $15 \mathrm{~mL}$ of hybridization solution (prehyb. solution with 10\% Dextran sulphate, $.5 \%$ powdered milk and 1\% SDS added) and boiled for 10 minutes. The tube was chilled to room temperature and added to the Seal- a-Meal bag containing the Zetaprobe membrane. This hybridization takes place in a $42^{\circ} \mathrm{C}$ incubator or water bath for four hours to overnight. Afterwards the hybridization solution is poured off and the membrane is removed from the bag. This was followed by four washes with $2 \times$ SSC and .1\% SDS. The first wash is for 15 minutes at room temperature and the subsequent washes are for 30 minutes at $60^{\circ} \mathrm{C}$. One seal a meal bag is used for the entire procedure. After each use it is cut open, emptied, refilled and sealed. A plastic container can also be used if one approximately the size of the gel can be found. After the final wash the filter was dried, placed on a sheet of 3MM paper and wrapped in Saran Wrap so that it was sealed, but the wrap wasn't overlapping at all. The wrapped film was placed in a cassette with 1 sheet of X-Ray film (Kodak XAR-5) and 
the cassette wrapped in foil and placed in a $-70^{\circ} \mathrm{C}$ freezer for 24 to 48 hours. I developed all the films after 2 days using a automatic developer for $X$-ray film. The fragment sizes on the film were determined by comparing the band distance to the molecular weight markers.

\section{TRANSFORMATION OF PCC7942 AND WH6501 WITH PLASMID pSG111}

Transformation of PCC7942 and WH6501 cells by the hybrid plasmid pSG111 was attempted using the methods of Golden and Sherman (1984). Cells were grown in $50 \mathrm{~mL}$ of their respective medias and spun down for $10 \mathrm{~min}$ at 10,000 rpm in a Sorval RC2B centrifuge. To $0.1 \mathrm{ml}$ of cells $0.1 \mu \mathrm{g}$ of DNA (pSG111) was added and incubated for 1 hour in the light with gentle mixing. The transformation mixture was plated on BG-11 and AQUIL media agar plates and incubated in the dark for $16 \mathrm{hr}$ at $30^{\circ} \mathrm{C}$ followed by $8 \mathrm{hr}$ under standard illumination. A range of concentrations of ampicillin $(20 \mu \mathrm{g} / \mathrm{ml}$ to $100 \mu \mathrm{g} / \mathrm{ml})$ was added to the plates by partially lifting the agar with a spatula and underlayering $.5 \mathrm{~mL}$ of desired antibiotic concentration. Transformed colonies appeared on the agar plates approximately 12 days following incubation with the pSG111 plasmid DNA and were then transferred to a liquid medium containing antibiotic. 